\title{
Neonate Bloodstream Infections in Organization for Economic Cooperation and Development Countries: An Update on Epidemiology and Prevention
}

\author{
Jadwiga Wójkowska-Mach ${ }^{1, * \mathbb{D}}$, Agnieszka Chmielarczyk ${ }^{1}$, Magdalena Strus ${ }^{1}$, \\ Ryszard Lauterbach ${ }^{2}$ and Piotr Heczko ${ }^{1}$ \\ 1 Department of Microbiology, Faculty of Medicine, Jagiellonian University Medical College, 31-121 Krakow, \\ Poland; agnieszka.chmielarczyk@uj.edu.pl (A.C.); mbstrus@cyf-kr.edu.pl (M.S.); \\ mbheczko@cyf-kr.edu.pl (P.H.) \\ 2 Neonatology Clinic, University Hospital, Jagiellonian University Medical College, 31-121 Kraków, Poland; \\ ryszard@lauterbach.pl \\ * Correspondence: jadwiga.wojkowska-mach@uj.edu.pl; Tel: +48-12-633-0060; Fax: +48-12-423-3924
}

Received: 16 September 2019; Accepted: 18 October 2019; Published: 21 October 2019

\begin{abstract}
The term neonatal sepsis is used to describe a generalized bloodstream infection of bacterial, viral, or fungal origin which is associated with hemodynamic changes and other clinical symptoms and signs, however, there is no unified definition. There are no basic criteria regarding differentiation of early-onset sepsis (EOS) versus late-onset sepsis (LOS). Stratification used in studies on neonatal sepsis also rarely includes the general condition of the newborn according to unambiguous assessment at birth, which hampers the establishment of a clear, uniform epidemiological description of neonatal sepsis. We aim to review the published data about the epidemiology and microbiology of sepsis in Organization for Economic Cooperation and Development (OECD) countries. Data was also collected on sepsis prevention programs that can be implemented in neonatal units. The outcomes of interest were incidence or incidence density of EOS and LOS, microbiology of EOS and LOS, and data on the methodology of the research, in particular the criteria for inclusion and exclusion of newborns from the study. Pubmed, EMBASE, LILACS Embase, Scopus, and Google Scholar were used. For the preselection step, inclusion criteria included: "bloodstream infection" or "neonatal sepsis" (MesH), "very low birth weight", and "country" full-text studies, human, and English language. Exclusion criteria included: studies published in languages other than English and studies available only as an abstracts. For proper selection, inclusion criteria included: information about epidemiology or microbiology bloodstream infection (BSI), study population and case definitions, exclusion criteria, narrative reviews, commentaries, case studies, pilot studies, study protocols, pediatric studies, and only clinical data (without microbiology or epidemiology) or studies with only one etiological factor analysis. The data review indicated the lack of an unequivocal, unified definition and no unambiguous basic criteria with regard to differentiation of EOS versus LOS. Among infants $<1500 \mathrm{~g}$, studies reported an EOS rate from $7 \%$ to $2 \%$. For studies using other definitions (mostly all inborn babies), the rate of EOS ranged from 1\% to 3\%. The LOS incidences were much more varied among countries; the highest rates were in the multicenter studies focused on very low birth weight (VLBW) infants. The main pathogens in EOS are GBS and Gram-negative bacteria in LOS. Our review data shows that LOS microbiology is very diverse and that Gram-positive cocci, especially staphylococci, predominate versus Gram-negative rods. Unfortunately, the lack of uniform, international prevention programs results in high newborn morbidity and insufficient postnatal prevention of late-onset infections.
\end{abstract}

Keywords: neonatal sepsis; bloodstream infections; very low birth weight neonates; epidemiology; prevention; probiotics 


\section{Introduction}

Infection in newborns, especially mild cases, remains a significant problem of contemporary medicine. In highly developed countries, one reason for this situation is the increasing number of multiple pregnancies and preterm births [1], such as in the United States (US), as compared with the period 1990 to 2007; the proportion of deliveries before 28 weeks of gestation in 1990 was $71 \%$ and $77 \%$ in 2007, and pregnancies with a higher number of fetuses (three and more) were observed twice more often than previously [2]. The second reason for the increasing proportion of infants among hospitalized patients is progression of survival rate of newborns with very low birth weight (VLBW) in modern neonatal intensive care units (NICU), however, this situation is invariably associated with high incidence of both early and late infections [3-8].

The most frequently observed infection in neonatal wards is bloodstream infection (BSI). According to a European point prevalence survey (2011-2012, based on European Center for Disease Prevention and Control (ECDC) methodology), BSI accounts for $44.6 \%$ of all healthcare-associated infections (HAIs) [9].

Thus, we aimed here to review and summarize the recently published data that most closely describe the incidence and microbiology of BSI in high-income countries. We chose Organization for Economic Cooperation and Development (OECD) countries as these have comparable rates of survival among premature infants. Data were also collected on BSI prevention programs and procedures that can be implemented in neonatal units.

\section{Methods}

\subsection{Data Sources}

The outcomes of interest were incidence or incidence density of EOS and LOS, microbiology of EOS and LOS, and data on the methodology of the research, in particular the criteria for inclusion and exclusion of newborns from the study. In the epidemiological and microbiological part of the study it was a two-stage search, performed by two review authors using MEDLINE via Pubmed, EMBASE, LILACS Embase, Scopus, and Google Scholar from 1980 to September 31, 2018. Two review authors independently performed a search concerning epidemiology and microbiology of BSI. The search was restricted to OECD countries [10]. The literature review on BSI prevention and control was performed by three review authors.

\subsection{Search Strategy and Study Selection}

For the preselection step, inclusion criteria included: "bloodstream infection" or "neonatal sepsis" (MesH), "very low birth weight", and "country" full-text studies, human, English language. Exclusion criteria included: studies published in languages other than English and studies available only as an abstracts.

For proper selection, inclusion criteria included: information about epidemiology or microbiology BSI, study population and case definitions, especially, data on BSI or neonatal sepsis microbiology and incidence rates with reported denominators, specified dates of the data collection period, and a description of the methods used including study population, the definition of BSI, and eligibility rules for early- and late-onset cases of BSI. Exclusion criteria included: narrative reviews, commentaries, case studies, pilot studies, study protocols, pediatric studies, and only clinical data (without microbiology or epidemiology) or studies with only one etiological factor analysis.

Initially, other sources of the data on incidence rates of neonatal sepsis etc. in non-English journals and governmental reports were also reviewed, but methodology and definitions used in these sources did not appear to be adequately precise, and therefore only the search described above was then presented. 
For proper selection, two author reviewers independently reviewed the titles and all abstracts. A study was eligible for inclusion if the epidemiology of BSI was provided at the national, regional, or multicenter level. In the case of a dearth of multicenter data, single-center study data were also included.

From the included studies, the following information data were extracted: country, case definition, study population, as well as and inclusion and exclusion criteria, time period, incidence rates and microbiology; if possible, we also extracted birth-weight specific BSI incidence rates and specific microbiology according to early-onset (EOS) or late-onset cases of BSI (LOS) or neonatal sepsis (Table 1). When there were multiple publications from the same country, the data from the most recent publication were only included once. 
Table 1. Characteristics of the collected studies on neonatal sepsis and bloodstream infections incidence rate in Organization for Economic Cooperation and Development (OECD) countries (in alphabetical order)

\begin{tabular}{|c|c|c|c|c|}
\hline Country & Population: Criteria of Including & $\begin{array}{c}\text { National/Regional Network or } \\
\text { Database }\end{array}$ & Case Definition & References \\
\hline $\begin{array}{l}\text { Austraila \& N. Zealand, } \\
\text { 2002-2012 }\end{array}$ & all inborn babies & $\begin{array}{c}\text { Australasian Study Group for Neonatal } \\
\text { Infections (ASGNI) }\end{array}$ & EOS: $48 \mathrm{~h}$ of life & [11] \\
\hline Australia, 2008-2016 & CLABSI and PLABSI in neonatal ICUs & $\begin{array}{c}\text { Victorian Healthcare Associated Infection } \\
\text { Surveillance System }\end{array}$ & $\begin{array}{l}\text { CDC definitions, NHSN methodology, LOS: } 48 \mathrm{~h} \\
\text { of life }\end{array}$ & [12] \\
\hline $\begin{array}{l}\text { Australia \& N. Zeland, } \\
\quad 2005-2007\end{array}$ & $\begin{array}{c}\text { all inborn babies, born }<32 \text { weeks of } \\
\text { gestation }\end{array}$ & 29 tertiary NICUs & EOS: $48 \mathrm{~h}$ of life & [13] \\
\hline Austria, 1988-1994 & all babies & 1 center study & EOS: $<7$ days of life & [14] \\
\hline Belgium, 2002-2011 & $\begin{array}{l}\text { all infants, inborn or hospitalised for } \\
\text { at least } 3 \text { days }\end{array}$ & 1 center study: tertiaty NICU & $\begin{array}{l}\text { LOS: more than } 72 \mathrm{~h} \text { of life, only } \\
\text { laboratory-confirmed BSI }\end{array}$ & [15] \\
\hline Canada, 2005-2007 & $\begin{array}{c}\text { all inborn babies, born }<32 \text { weeks of } \\
\text { gestation }\end{array}$ & 26 tertiary NICUs & EOS: $72 \mathrm{~h}$ of life & [13] \\
\hline Denmark, 2010-2013 & $\begin{array}{l}\text { all infants, inborn or hospitalised } \\
\text { born }<28 \text { weeks of gestation }\end{array}$ & 1 center study: tertiaty NICU & $\begin{array}{c}\text { EOS: }<7 \text { days of life, only laboratory-confirmed } \\
\text { BSI }\end{array}$ & [16] \\
\hline Denmark, 2005 & all infants, inborn or hospitalised & 1 center study: tertiaty NICU & $\begin{array}{l}\text { LOS: more than } 48 \mathrm{~h} \text { of life, only } \\
\text { laboratory-confirmed BSI }\end{array}$ & [17] \\
\hline Estonia, 2004-2008 & all inborn babies & $\begin{array}{l}1 \text { center study: NICU and paediatric } \\
\text { intensive care unit }\end{array}$ & CDC definitions, only laboratory-confirmed BSI & [18] \\
\hline Finland, 1999-2006 & all inborn babies & 1 center study & CDC definitions, only laboratory-confirmed BSI & [19] \\
\hline France, 2004-2005 & all inborn babies & Alsace, 9 tertiary NICUs & EOS: $72 \mathrm{~h}$ of life & [20] \\
\hline France, 2007 & all inborn babies & Alsace, 9 tertiary NICUs & LOS: between $72 \mathrm{~h}$ and 90 days of life & [21] \\
\hline Germany, 2000-2005 & VLBW infants & Neo-KISS & Neo-KISS definition, LOS: more than $72 \mathrm{~h}$ of life & [22] \\
\hline Germany, 2010-2011 & VLBW infants & Neo-KISS & Neo-KISS definition, LOS: more than $72 \mathrm{~h}$ of life & [23] \\
\hline Greek, 2012-2015 & $\begin{array}{l}\text { neonates admitted to participating } \\
\text { NNUs }\end{array}$ & $\begin{array}{l}16 \text { NICUs participating in the neonIN } \\
\text { infection surveillance network }\end{array}$ & $\begin{array}{l}\text { EOS: } 48 \mathrm{~h} \text { of life, positive blood, cerebrospinal } \\
\text { fluid or urine culture and were treated with at } \\
\text { least } 5 \text { days of antibiotics }\end{array}$ & [24] \\
\hline Ireland, 2001-2014 & $\begin{array}{l}\text { all newborn infants, only } \\
\text { "culture-proven" }\end{array}$ & 1 center study: tertiaty NICU & $\begin{aligned} \text { EOS: }<7 \text { days of life, LOS more than } 7 \text { days of life } \\
\text { only laboratory-confirmed BSI }\end{aligned}$ & [25] \\
\hline Israel, 1995-1998 & VLBW infants survived at least 3 days & national cohort & LOS: more than $72 \mathrm{~h}$ of life & [26] \\
\hline Israel, 1995-2005 & VLBW infants & Israel Neonatal Network & undefined & [27] \\
\hline
\end{tabular}


Table 1. Cont

\begin{tabular}{|c|c|c|c|c|}
\hline Country & Population: Criteria of Including & $\begin{array}{c}\text { National/Regional Network or } \\
\text { Database }\end{array}$ & Case Definition & References \\
\hline Israel, 2007-2013 & population-based study & 1 center study & EOS: $<7$ days of life & [28] \\
\hline Italy, 2006-2010 & all inborn babies & 1 center study & CLABSI only & [29] \\
\hline Japan, 2006 to 2008 & $\begin{array}{l}\text { all newborn infants, only } \\
\text { "culture-proven" }\end{array}$ & 5 NICUs & only laboratory-confirmed BSI & [30] \\
\hline Mexico, 2004-2007 & $\begin{array}{l}\text { neonates admitted to the neonatal } \\
\text { ICUs }\end{array}$ & 1 center study & LOS: more than $72 \mathrm{~h}$ of life & [31] \\
\hline Netherlands, 2007 & all infants with catheter & 1 center study & CLABSI only & [32] \\
\hline North America, 1997-2010 & VLBW infants & 313 NICUs & $\begin{array}{l}\text { LOS: more than } 72 \mathrm{~h} \text { of life, only } \\
\text { laboratory-confirmed BSI }\end{array}$ & [33] \\
\hline Norwey, 1999-2000 & $\begin{array}{l}\text { all infants with gestational age of }<28 \\
\text { weeks or birth weight of }<1000 \mathrm{~g}\end{array}$ & $\begin{array}{l}\text { national cohort of extremely premature } \\
\text { infants }\end{array}$ & EOS: diagnosed to day 7 of life & {$[34,35]$} \\
\hline Poland, 2009 & VLBW infants & $\begin{array}{l}\text { Polish Neonatology Surveillance } \\
\text { Network }\end{array}$ & Neo-KISS definition, EOS: $72 \mathrm{~h}$ of life & {$[36,37]$} \\
\hline $\begin{array}{l}\text { South America countries, } \\
\text { 2001-2013 }\end{array}$ & inborn VLBW infants & 26 tertiary NICUs & LOS: more than $72 \mathrm{~h}$ of life & [38] \\
\hline South Korea, 1997-1999 & all infants, inborn or hospitalised & 4 neonatal centers & LOS: more than $72 \mathrm{~h}$ of life & [39] \\
\hline Spain, 2002-2005 & VLBW infants & $\begin{array}{l}\text { SEN1500 network by Spanish Society of } \\
\text { Neonatology }\end{array}$ & undefined & [40] \\
\hline Sweden, 2004-2007 & $\begin{array}{l}\text { extremely premature infants, born } \\
\text { before } 27 \text { weeks of gestation and } \\
\text { survived their first year of life }\end{array}$ & $\begin{array}{l}\text { nationwide Swedish prospective cohort } \\
\text { study }\end{array}$ & $\begin{array}{l}\text { only clinical sepsis with negative blood culture } \\
\text { and treated for a min. of } 5 \text { days }\end{array}$ & [41] \\
\hline Switzerland, 2011-2015 & $\begin{array}{l}\text { all newborn infants admitted to } \\
\text { tertiary care ICUs }\end{array}$ & the Swiss Pediatric Sepsis Study & $\begin{array}{c}\text { EOS: } 72 \mathrm{~h} \text { of life and/or LOS if onset of infection } \\
\text { was } \leq 48 \mathrm{~h} \text { after admission, only } \\
\text { laboratory-confirmed BSI }\end{array}$ & [42] \\
\hline Turkey, 2003-2010 & $\begin{array}{l}\text { preterm infants with gestational age } \\
\text { of }<37 \text { weeks, only "culture-proven" }\end{array}$ & 1 center study & $\begin{array}{c}\text { EOS: } 72 \mathrm{~h} \text { of life, LOS more than } 72 \mathrm{~h} \text { of life, only } \\
\text { laboratory-confirmed BSI }\end{array}$ & [43] \\
\hline United Kingdom, 2005-2014 & undefined & neonIN: 30 NICUs & $\begin{array}{l}\text { only laboratory-confirmed BSI treated with at } \\
\text { least } 5 \text { days of appropriate antibiotics }\end{array}$ & [44] \\
\hline USA, 1998-2000 & $\begin{array}{l}\text { VLBW and extremely premature } \\
\text { infants }\end{array}$ & $\begin{array}{l}\text { national: NICHD Neonatal Research } \\
\text { Network }\end{array}$ & EOS: $72 \mathrm{~h}$ of life & [45] \\
\hline
\end{tabular}

CLABSI, central line-associated bloodstream infection; PLABSI, peripheral venous catheter-associated bloodstream infection; EOS, early-onset sepsis; CDC, Centers for Disease Control; LOS, late-onset sepsis; VLBW, very low birth weight; BSI, bloodstream infection; NICU, neonatal intensive care units, 


\section{Results}

A total of 4871 articles were identified, 199 articles were included in the proper selection stage after being screened according to titles and abstracts. Finally, 35 studies which fulfilled the eligibility criteria were included for the review (Table S1).

The included studies represented data from 27 of the 36 OECD countries, primarily across Europe, Asia, and the US (Table 1). There were more available data on incidence rate (30 studies, 26 countries) than on microbiology of early-onset EO and late-onset LO BSI (28 studies, 25 countries). The country, time period, case definition applied, and incidence rates of BSI in the included studies are shown in Table 1.

Fourteen studies were multicenter studies [11-13,24,26,27,30,33,36-40,42,44,45] one was a regional study [20], and five were national studies [22-24,27,34,35,41], however, twelve studies were single-center studies [14-19,25,28,29,31,32,43] (Table 1). Most study populations comprised inborn babies admitted to the neonatal unit. Inclusion criteria were based on birth weight (mostly below $1500 \mathrm{~g}$ ) or gestational age, most accounted for all inborn babies (17 studies). In two studies, from Italy and Netherlands, the surveillance included only neonates with catheters (peripheral or central venous catheter, CVC). One study included a national cohort of extremely premature infants, Norway. With the exception of studies from the US (1991-1993), Austria (1988-1994), and France (1984) all studies included data from the last 20 years. The studies from Belgium, Finland, Australia, and New Zealand, and Israel covered the longest periods.

Limited data were retrieved from some regions and many countries, but $25.7 \%$ of the OECD countries were not represented. Furthermore $12(35.3 \%)$ studies were single-center studies with unknown representativeness.

\subsection{Case Definitions for BSI}

It is generally accepted to use the term neonatal sepsis to describe a systemic condition initially evoked by bacteria, viruses, or fungi and which is accompanied with hemodynamic changes and other clinical manifestations leading to substantial morbidity and mortality in neonates, however, despite many years of clinical experience in diagnosis and treatment of neonates with confirmed or suspected sepsis, there is no commonly accepted definition of neonatal sepsis. Sometimes, the definition of sepsis erroneously includes isolation of a pathogen from normally sterile body fluid, such as blood or cerebrospinal fluid, which laboratory finding should be described as bacteremia. Since practically all clinical features and laboratory data of sepsis are induced by a burst of the potent proinflammatory cytokines, the term clinical sepsis (or systemic inflammatory response syndrome, SIRS) has also been used in literature in parallel to neonatal sepsis [46,47]. From an epidemiological point of view sepsis is a bloodstream infection (BSI).

Unfortunately, our data review indicated the lack of an unequivocal, unified definition. There are no unambiguous basic criteria with regard to differentiation of EOS versus LOS. Stratification in the research also rarely includes newborns' general condition according to unambiguous assessment at birth; most program data refer to "inborn babies" without additional qualifying criteria. Both of these factors make it impossible to establish a clear description of the epidemiology of neonatal sepsis.

In multicenter studies targeting VLBW neonates, the most commonly applied definition was that of the Centers for Disease Control and Prevention (CDC), used in three studies. The definition used in the Neo-KISS (a surveillance system for VLBW infants in Germany) and ECDC was applied in two studies (Poland and Germany) (Table 1). The remaining studies used their own definition, based on a combination of clinical signs and different time to recognition of EOS and LOS, mostly 48 or $72 \mathrm{~h}$ of life, but sometimes this was five or seven days (Table 1). 


\subsection{Comparison of BSI Rate by Case Definition, Date of Onset (Early and Late), and Birth Weight Category}

We present the rate of BSI by case definition, gestational age, and birth weight category (Table 2). Among infants $<1500 \mathrm{~g}$, studies using CDC or Neo-KISS definitions reported an EOS rate of $7 \%$ in Poland, $5 \%$ in Spain, and about $2 \%$ in the US and Israel. For studies using other definitions (mostly all inborn babies), the rate of EOS ranged around 1\% to 3\%, except $6.6 \%$ in Denmark. In a Norwegian national cohort of extremely premature infants, the EOS rate was 3.6\% (Table 2).

Table 2. Comparison of the early-onset (EO) versus late-onset sepsis (LO)/bloodstream infections incidence rate (in alphabetical order).

\begin{tabular}{|c|c|c|c|}
\hline Country & Rate of EO Sepsis & Rate of LO Sepsis & References \\
\hline $\begin{array}{l}\text { Australia \& N. Zealand, } \\
\text { 2005-2007 }\end{array}$ & $1.7 \%$ & $15.1 \%$ & [13] \\
\hline Australia, 2008-2016 & $\mathrm{n} / \mathrm{a}$ & $\begin{array}{l}\text { CLABSI: } 2.20 \text { per } 1000 \text { CVC-days } \\
\text { PLABSI: } 0.67 \text { per } 1000 \\
\text { peripheral line-days }\end{array}$ & [12] \\
\hline Austria, 1988-1994 & $1.9 \%$ & $4.6 \%$ & [14] \\
\hline Belgium, 2002-2011 & $\mathrm{n} / \mathrm{a}$ & $7.1 \%$ & [15] \\
\hline Canada, 2005-2007 & $1.3 \%$ & $18.7 \%$ & [13] \\
\hline $\begin{array}{l}\text { Denmark, 2010-2013 / } \\
2005\end{array}$ & $6.6 \%$ & $7.6 \%$ & {$[16,17]$} \\
\hline Estonia, 2004-2008 & $\mathrm{n} / \mathrm{a}$ & $9.2 \%$ and 12.8 per $1000 \mathrm{pds}$ & [18] \\
\hline Finland, 1999-2006 & $\mathrm{n} / \mathrm{a}$ & $3.2 \%$ & [19] \\
\hline France, 2004-2005 & $1.08 \%$ & $\mathrm{n} / \mathrm{a}$ & [20] \\
\hline France, 2007 & $\mathrm{n} / \mathrm{a}$ & $4.9 \%$ & [21] \\
\hline Germany, 2010-2011 & $\mathrm{n} / \mathrm{a}$ & 5.7 per 1000 pds & [23] \\
\hline Greek, 2012-2015 & $0.4 \%$ & $4.5 \%$ & [24] \\
\hline Ireland, 2001-2014 & $0.1 \%$ & $0.2 \%$ & [25] \\
\hline Israel, 1995-1998 & $\mathrm{n} / \mathrm{a}$ & $30.1 \%$ & [26] \\
\hline Israel. 1995-2005 & $2.4 \%$ & $\mathrm{n} / \mathrm{a}$ & [27] \\
\hline Japan, 2006-2008 & $0.13 \%$ & $0.61 \%$ & [30] \\
\hline Mexico, 2004-2007 & $3.28 \%$ & $1.08 \%$ & [31] \\
\hline Netherlands, 2007 & $\mathrm{n} / \mathrm{a}$ & $\begin{array}{l}18.1 \text { per } 1000 \text { pds CLABSI, } \\
\text { catheter-associated BSI, only }\end{array}$ & [32] \\
\hline $\begin{array}{l}\text { North America, } \\
19978-2010\end{array}$ & $1.0 \%$ & $12.2 \%$ & [33] \\
\hline Norway, 1999-2000 & $3.6 \%$ & $9.7 \%$ & {$[34,35]$} \\
\hline Poland, 2009 & $7.0 \%$ & $\begin{array}{c}25.3 \% \\
\text { CLABSI: } 8.6 \text { per } 1000 \text { CVC-days } \\
\text { PLABSI: } 10.5 \text { per } 1000 \\
\text { peripheral line-days }\end{array}$ & {$[36,37]$} \\
\hline $\begin{array}{l}\text { South America countries, } \\
\text { 2001-2013 }\end{array}$ & $\mathrm{n} / \mathrm{a}$ & $22.2 \%$ & [38] \\
\hline South Korea, 1997-1999 & 29.3 per 1000 live births & 7.2 per 1000 live births & [39] \\
\hline Spain, 2002-2005 & $5.0 \%$ & $29.4 \%$ & [40] \\
\hline Sweden, 2004-2007 & & $66 \%$ & [41] \\
\hline Switzerland, 2011-2015 & 0.28 per 1000 live births & 0.86 per 1000 live births & [42] \\
\hline Turkey, 2003-2010 & $2.3 \%$ & $12.9 \%$ & [43] \\
\hline $\begin{array}{l}\text { United Kingdom, } \\
\text { 2005-2014 }\end{array}$ & $\begin{array}{c}0.7 \text { per } 1000 \text { live births } \\
\text { and } 5.5 \text { per } 1000 \text { neonatal } \\
\text { admissions }\end{array}$ & $\begin{array}{l}\text { 6.1 per } 1000 \text { live births and } 48.8 \\
\text { per } 1000 \text { neonatal admissions }\end{array}$ & [44] \\
\hline USA, 1998-2000 & $1.5 \%$ & $21 \%$ & [45] \\
\hline
\end{tabular}

central line catheter-associated bloodstream infections, CLABSI; patient days, pds; peripheral venous catheter-associated bloodstream infections, PLABSI; CVC, central venous catheter. 
The LOS incidence rate was much more varied among countries; the highest rates were in the US, South American countries, Poland, and Spain in multicenter studies focused on VLBW infants. In a few studies, incidence rates were stratified by birth weight or gestational age (Table 3), the incidence rates were surprisingly similar in the US and Poland, and rates in Germany were lower in each newborn group (Table 3).

Table 3. Comparison of the late-onset (LO) sepsis incidence rates stratified by birth weight or gestation age (in alphabetical order).

\begin{tabular}{|c|c|c|c|c|c|}
\hline Country & \multicolumn{4}{|c|}{ Rate of LO Sepsis: Stratification by Birth Weight or Gestation Age } & \multirow{2}{*}{$\begin{array}{c}\text { References } \\
{[12]}\end{array}$} \\
\hline $\begin{array}{c}\text { Australia and N. } \\
\text { Zealand, 2005-2007 }\end{array}$ & $<25$ weeks: 2.7 & $\begin{array}{l}\text { 25-26 weeks: } \\
2.8\end{array}$ & $\begin{array}{c}\text { 27-28 weeks: } \\
2.0\end{array}$ & $\begin{array}{l}\text { 29-31 weeks: } \\
2.2\end{array}$ & \\
\hline Canada, 2005-2007 & $<25$ weeks: 3.2 & $\begin{array}{l}\text { 25-26 weeks: } \\
2.3\end{array}$ & $\begin{array}{l}\text { 27-28 weeks: } \\
1.2\end{array}$ & $\begin{array}{l}\text { 29-31 weeks: } \\
0.7\end{array}$ & [13] \\
\hline $\begin{array}{l}\text { Germany, } \\
\text { 2010-2011 }\end{array}$ & \multicolumn{2}{|c|}{$<1000$ g: 8.5 per 1000 pds } & \multicolumn{2}{|c|}{$1001-1499$ g: 4.0 per 1000 pds } & [22] \\
\hline Italy, 2006-2010 & $\begin{array}{l}<750 \text { g: } 11.6 \text { per } \\
1000 \text { pds }^{*}\end{array}$ & $\begin{array}{l}\text { 751-1000 g: } 8.6 \\
\text { per } 1000 \text { pds * }\end{array}$ & \multicolumn{2}{|c|}{ 1001-1500 g: 4.7 per 1000 pds * } & [29] \\
\hline Poland, 2009 & $<750$ g: $44.6 \%$ & $\begin{array}{c}\text { 751-1000 g: } \\
31 \%\end{array}$ & \multicolumn{2}{|c|}{$1001-1500$ g: $18.0 \%$} & {$[36,37]$} \\
\hline USA, 1998-2000 & $<750$ g: $42.8 \%$ & $\begin{array}{c}751-1000 \mathrm{~g}: \\
28 \%\end{array}$ & \multicolumn{2}{|c|}{ 1001-1500 g: $11.0 \%$} & [45] \\
\hline
\end{tabular}

* catheter-associated bloodstream infections, CLABSI only; pds, patient days.

In studies including or limited to catheter-associated BSI, the central line-associated bloodstream infection (CLABSI) incidence was comparable. In the Netherlands, this was 18.1/1000 patient days (pds) and 8.6/1000 pds in Poland. In Italy, this incidence was 4.7/1000 to 11.6/1000 pds, depending on birth weight, similar to an Australian study reporting 1.2/1000 to 3.5/1000 CVC-pds. Completely different results were found in the analysis of peripheral venous catheter -associated bloodstream infection (PLABSI) incidence. In Australia, this was 0.67/1000 peripheral line-pds, but the incidence was much higher in Poland, with 10.5/1000 peripheral line-pds.

There were some differences in the epidemiology of neonatal infections (both EOS and LOS) among the analyzed studies included in this review. The main source of these differences were most likely distinctions used by the authors in applying various parameters to describe the status of neonates at birth or the risk of infection, as well as time lapses between birth and the onset of infection, such as $48 \mathrm{~h}$ of life or $72 \mathrm{~h}$ of life or seven days. Likewise, different groups of neonates were used as denominators, i.e., all infants born versus VLBW newborns only. Moreover, different definitions of sepsis were applied. In a few studies, the basis for the diagnosis sepsis was a single positive blood culture and prolonged antibiotic therapy. No validation of the detection and qualification of sepsis cases was found in any studies.

The most important factor that was also closely related to intensive care in neonatal wards seemed to be stratification of cases into groups according to the risk of infection. Unfortunately, this methodology was applied in only a few studies, however, the most frequently used qualification was based on gestational weight as this parameter is easy to obtain, independent from other variables, and involves no danger of underestimation in comparison with gestational age, which is more subjective because it relies on cooperation between the obstetrician and parturient. Stratification of neonates according to gestational weight should be preferred in studies on the epidemiology of neonatal infections as it is used in two of the most important research projects on neonatal infections, the National Healthcare Safety Network (NHSN) and ECDC programs.

\subsection{Microbiology of BSI}

In EOS, Gram-positive bacteria predominated, particularly group B Streptococcus (GBS); the highest percentage values were reported in French (58.5\%) and British (43\%) studies (Table 4). In Swedish 
research, a similar number of infections were caused by GBS (20\%), coagulase-negative staphylococci (CoNS, 30\%) and Escherichia coli (25\%). The situation differed in South Korea and Denmark, where the main pathogen in EOS was S. aureus (48\% and 36.6\%). Mexico and Turkey dominated CoNS with a prevalence of $55.5 \%$ and $60.9 \%$, respectively (Table 4 ).

Among Gram-negative bacilli, the most frequently occurring was E. coli, which was associated with approximately $20 \%$ of cases. E. coli predominated in EOS in a study from Israel and two studies from North America; with respect to the latter, E. coli occurred in $33.4 \%$ of cases, whereas in the US alone, the rate was $44 \%$. In early infections in Poland, GBS was common (20\%), but an additional problem in that country is infections caused by Klebsiella pneumoniae (22\%), also in EOS (Table 4).

Infections caused by fungi in EOS accounted for $2 \%$ to $3 \%$ of cases and the highest level was $8 \%$ in Poland (Table 4).

In LOS, CoNS was significantly predominant, from $24.2 \%$ in Australia to $75 \%$ in the UK and $85 \%$ in the Netherlands, most often in $30 \%$ to $50 \%$ of infections. France differed in that more than half of infections (55.5\%) were caused by E. coli. In Japan, the main pathogen in LOS was S. aureus (26\% and similar in Ireland, 26.9\%) apart from E.coli and Klebsiella and other Gram-negative bacillis (24\%); unexpectedly Pseudomonas spp. were also common (12\%) (Table 5). In South Korea, among Gram-positive bacteria, both CoNS and S. aureus were predominant (37.5\% and 36\%, respectively). Infections caused by Gram-negative pathogens in LOS ranged from $7 \%$ in Finland to $64.4 \%$ in United Kingdom and yeast-like fungal infections were more common than in the case of EOS, from $2 \%$ in Switzerland to $18.8 \%$ in Turkey (Table 5).

CLABSI were very strongly associated with CoNS; this was the case in Dutch $(85 \%)$ and Australian $(24.2 \%)$ studies, in line with the researchers' expectations, however, in an Italian study of CLABSI, half of infections ( $50 \%$ ) were caused by yeast-like fungi (Table 5 ).

In summary, a predominance of Gram-positive cocci, especially GBS, was confirmed among bacteria isolated from EOS cases. CoNS was most often found in LOS related to CLABSI and PLABSI, although a broader range of microorganisms, including Gram-negative rods, was noted in LOS cases (Table 5). 
Table 4. Share of the most common species of Gram-positive cocci, Gram-negative bacilli, and fungi in early-onset neonatal sepsis (in alphabetical order).

\begin{tabular}{|c|c|c|c|c|c|c|c|c|c|}
\hline \multirow[t]{2}{*}{ Organism } & \multicolumn{4}{|c|}{ Gram-Positive Cocci (\%) } & \multicolumn{3}{|c|}{ Gram-Negative Bacilli (\%) } & \multirow{2}{*}{ Fungi } & \multirow{2}{*}{ References } \\
\hline & $\begin{array}{c}\text { Staphylococcus } \\
\text { aureus }\end{array}$ & $\begin{array}{l}\text { Coagulase-negative } \\
\text { staphylococci }\end{array}$ & $\begin{array}{c}\text { Group B } \\
\text { Streptococcus }\end{array}$ & others & $\begin{array}{c}\text { Escherichia } \\
\text { coli }\end{array}$ & $\begin{array}{l}\text { Klebsiella } \\
\text { spp. }\end{array}$ & others & & \\
\hline $\begin{array}{c}\text { Australia and N. Zealand, } \\
\text { 2002-2012 }\end{array}$ & 3.0 & 6.0 & 37.0 & 16.5 & 25.0 & $\mathrm{n} / \mathrm{a}$ & 12.5 & 1.0 & [11] \\
\hline Australia, 2008-2016 & \multicolumn{7}{|c|}{ Only LO sepsis } & & [12] \\
\hline Austria, 1988-1994 & 6.3 & 12.5 & 28.1 & 21.9 & 0.0 & 9.4 & 18.8 & 3.1 & [14] \\
\hline Belgium & \multicolumn{7}{|c|}{ Only LO sepsis } & & [15] \\
\hline Denmark & 36.0 & $\mathrm{n} / \mathrm{a}$ & 27.0 & 9.0 & 14.0 & 9.0 & 5.0 & $\mathrm{n} / \mathrm{a}$ & [16] \\
\hline Estonia, 2004-2008 & \multicolumn{7}{|c|}{ Only LO sepsis } & & [18] \\
\hline Finland, 1999-2006 & \multicolumn{7}{|c|}{ Only LO sepsis } & & [19] \\
\hline France, 2004-2005 & 1.8 & 2.4 & 58.5 & 9.4 & 22.4 & 0.6 & 4.5 & $\mathrm{n} / \mathrm{a}$ & [20] \\
\hline France, 2007 & \multicolumn{8}{|c|}{ Only LO sepsis } & [21] \\
\hline Germany, 2002-2005 & \multicolumn{8}{|c|}{ Only LO sepsis } & [22] \\
\hline Greek, 2012-2015 & $\mathrm{n} / \mathrm{a}$ & 17.4 & 13.0 & 30.4 & 17.4 & 4.3 & 15.2 & 2.2 & [24] \\
\hline Ireland & 12.6 & 14.1 & 38.5 & $\mathrm{n} / \mathrm{a}$ & 14.1 & $\mathrm{n} / \mathrm{a}$ & $\mathrm{n} / \mathrm{a}$ & $\mathrm{n} / \mathrm{a}$ & [25] \\
\hline Israel, 1995-1999 & \multicolumn{8}{|c|}{ Only LO sepsis } & [26] \\
\hline Israel, 1995-2005 & $\mathrm{n} / \mathrm{a}$ & 17.2 & 9.4 & $\mathrm{n} / \mathrm{a}$ & 26.8 & $\mathrm{n} / \mathrm{a}$ & $\mathrm{n} / \mathrm{a}$ & 3.0 & [27] \\
\hline Italy, 2006-2010 & \multicolumn{8}{|c|}{ Only LO sepsis } & [29] \\
\hline Japan, 2006 to 2008 & \multicolumn{8}{|c|}{ Only LO sepsis } & [30] \\
\hline Mexico, 2004-2007 & 0.0 & 55.5 & 22.2 & $\mathrm{n} / \mathrm{a}$ & 11.1 & 11.1 & 0.0 & 0.0 & [31] \\
\hline Netherlands, 2007 & \multicolumn{8}{|c|}{ Only LO sepsis } & [32] \\
\hline Norway, 1999-2000 & 18.5 & 25.9 & 11.1 & 3.7 & 33.3 & 3.7 & 0.0 & 3.7 & {$[34,35]$} \\
\hline North America, 1997-2010 & 2.1 & 2.3 & 18.2 & 2.9 & 33.4 & 1.5 & 11.7 & 2.7 & [33] \\
\hline Poland, 2009 & 4.0 & 16.0 & 20.0 & 14.0 & 12.0 & 4.0 & 22.0 & 8.0 & {$[36,37]$} \\
\hline $\begin{array}{l}\text { South America countries } \\
\text { (including Chile), 2001-2013 }\end{array}$ & \multicolumn{8}{|c|}{ Only LO sepsis } & {$[38]$} \\
\hline South Korea, 1997-1999 & 48.0 & 27.2 & 1.6 & 7.4 & 9.9 & $\mathrm{n} / \mathrm{a}$ & $\mathrm{n} / \mathrm{a}$ & 3.3 & [39] \\
\hline Sweden, 2004-2007 & 0.0 & 30.0 & 20.0 & 0.0 & 25.0 & 5.0 & 5.0 & 5.0 & [41] \\
\hline Switzerland, 2011-2015 & 2.0 & 8.0 & 38.0 & 23.0 & 23.0 & $\mathrm{n} / \mathrm{a}$ & 6.0 & 0.0 & [42] \\
\hline Turkey & 4.3 & 60.9 & 8.7 & 8.7 & 4.3 & 0.0 & 13.0 & 0.0 & [43] \\
\hline United Kingdom, 2005-2014 & $\mathrm{n} / \mathrm{a}$ & $\mathrm{n} / \mathrm{a}$ & 43.0 & $\mathrm{n} / \mathrm{a}$ & 18.0 & $\mathrm{n} / \mathrm{a}$ & $\mathrm{n} / \mathrm{a}$ & 0.8 & [44] \\
\hline USA, 1998-2000 & $\mathrm{n} / \mathrm{a}$ & 10.7 & 10.7 & 15.5 & 44.0 & $\mathrm{n} / \mathrm{a}$ & 16.7 & 2.4 & [45] \\
\hline
\end{tabular}


Table 5. Share of the most common species of Gram-positive cocci, Gram-negative bacilli, and fungi in late-onset neonatal sepsis (in alphabetical order).

\begin{tabular}{|c|c|c|c|c|c|c|c|c|c|}
\hline \multirow[t]{2}{*}{ Organism } & \multicolumn{4}{|c|}{ Gram-Positive Cocci (\%) } & \multicolumn{3}{|c|}{ Gram-Negative Bacilli (\%) } & \multirow{2}{*}{ Fungi } & \multirow{2}{*}{ References } \\
\hline & $\begin{array}{c}\text { Staphylococcus } \\
\text { aureus }\end{array}$ & $\begin{array}{l}\text { Coagulase-negative } \\
\text { staphylococci }\end{array}$ & $\begin{array}{c}\text { Group B } \\
\text { Streptococcus }\end{array}$ & others & $\begin{array}{l}\text { Escherichia } \\
\text { coli }\end{array}$ & $\begin{array}{l}\text { Klebsiella } \\
\text { spp. }\end{array}$ & others & & \\
\hline $\begin{array}{l}\text { Australia and N. Zealand, } \\
\text { 2002-2012 }\end{array}$ & \multicolumn{8}{|c|}{ Only EO sepsis } & [11] \\
\hline Australia *, 2008-2016 & 16.1 & 24.2 & $\mathrm{n} / \mathrm{a}$ & 11.3 & 11.1 & 11.6 & 19.1 (including 8.8 Enterobacter) & 5.6 & [12] \\
\hline Austria, 1988-1994 & 4.9 & 33.3 & 0.0 & 21.0 (Enterococcus spp. only) & 1.2 & 2.5 & 22.2 & 18.5 & [14] \\
\hline Belgium & 16.4 & 51.2 & 1.5 & 12.0 & 6.1 & 2.9 & 7.9 & 1.8 & [15] \\
\hline Denmark & 5.8 & 26.9 & $\mathrm{n} / \mathrm{a}$ & $\mathrm{n} / \mathrm{a}$ & 1.9 & $\mathrm{n} / \mathrm{a}$ & 3.8 & 1.9 & [17] \\
\hline Estonia, 2004-2008 & 5.5 & 48.6 & $\mathrm{n} / \mathrm{a}$ & 8.3 & $\mathrm{n} / \mathrm{a}$ & 7.3 & 23.8 (including Serratia spp. 12.0) & 3.7 & [18] \\
\hline Finland, 1999-2006 & 7.0 & 65.0 & $\mathrm{n} / \mathrm{a}$ & 6.3 & 3.0 & 3.0 & 1.0 & 9.0 & [19] \\
\hline France, 2004-2005 & \multicolumn{8}{|c|}{ Only EO sepsis } & [20] \\
\hline France, 2007 & 12.7 & 13.6 & 7.3 & $\mathrm{n} / \mathrm{a}$ & 55.5 & $\mathrm{n} / \mathrm{a}$ & $\mathrm{n} / \mathrm{a}$ & $\mathrm{n} / \mathrm{a}$ & [21] \\
\hline Germany, 2000-2005 & 9.8 & 54.2 & $\mathrm{n} / \mathrm{a}$ & 3.9 & 4.6 & 6.3 & 6.4 & 3.1 & [22] \\
\hline Greek, 2012-2015 & 0.5 & 31.5 & 0.2 & 7.0 & 13.0 & 19.4 & 17.7 (including 8.0 Enterobacter) & 10.7 & [24] \\
\hline Ireland & 26.9 & 22.1 & 7.7 & 11.1 & 10.6 & 10.6 & $\mathrm{n} / \mathrm{a}$ & $\mathrm{n} / \mathrm{a}$ & [25] \\
\hline Israel, 1995-1999 & 3.9 & 47.3 & 0.3 & 2.9 & 2.8 & 14.7 & 10.3 & 11.1 & [26] \\
\hline Israel, 1995-2005 & \multicolumn{8}{|c|}{ Only EO sepsis } & [27] \\
\hline Italy **, 2006-2010 & 2.1 & 4.2 & $\mathrm{n} / \mathrm{a}$ & 2.1 & 8.3 & 6.3 & 16.7 & 50.0 & [29] \\
\hline Japan, 2006 to 2008 & 26.0 & 12.0 & 7.0 & 14.0 & 12.0 & 5.0 & 24.0 (including 12.0 Pseudomonas spp.) & $\mathrm{n} / \mathrm{a}$ & [30] \\
\hline Mexico, 2004-2007 & 16.7 & 47.4 & 2.6 & 0.0 & 2.6 & 5.1 & 8.9 & 16.7 & [31] \\
\hline Netherlands ${ }^{* *}, 2007$ & 2.5 & 85.0 & $\mathrm{n} / \mathrm{a}$ & 2.5 & 2.5 & 2.5 & 2.5 & 2.5 & [32] \\
\hline Norwey, 1999-2000 & 12.0 & 47.0 & 9.0 & 2.0 & 1.0 & 8.0 & 10.0 & 10.0 & {$[34,35]$} \\
\hline North America, 1997-2010 & 15.4 & 28.3 & 3.1 & 6.8 & 6.2 & 6.8 & 9.6 & 10.5 & [33] \\
\hline Poland, 2009 & 7.8 & 62.7 & n/a & 6.6 & 6.6 & 6.8 & 5.9 & 3.8 & {$[36,37]$} \\
\hline $\begin{array}{l}\text { South America countries } \\
\text { (including Chile), 2001-2013 }\end{array}$ & 8.7 & 44.3 & $\mathrm{n} / \mathrm{a}$ & 5.7 & 3.8 & 9.5 & 5.6 & 7.0 & [38] \\
\hline South Korea, 1997-1999 & 36.0 & 37.5 & 0.0 & 7.8 & 7.8 & $\mathrm{n} / \mathrm{a}$ & $\mathrm{n} / \mathrm{a}$ & 10.9 & [39] \\
\hline Sweden, 2004-2007 & 5.9 & 67.8 & 2.0 & 3.0 & 1.3 & 3.6 & 4.2 & 6.9 & [41] \\
\hline Switzerland, 2011-2015 & 15.3 & 36.5 & 15.3 & 9.1 & 24.7 & $\mathrm{n} / \mathrm{a}$ & 13.0 & 2.3 & [42] \\
\hline Turkey & 5.5 & 49.2 & 5.5 & 4.7 & 0.8 & 3.9 & 11.7 & 18.8 & [43] \\
\hline United Kingdom, 2005-2014 & 8.0 & 75.0 & 5.0 & 12.8 & 32.0 & 21.0 & 11.6 & 4.0 & [44] \\
\hline USA, 1998-2000 & 7.8 & 47.9 & 2.3 & 12.2 & 4.9 & 4.0 & 8.5 & 13.9 & [45] \\
\hline
\end{tabular}

Notes: * central line catheter-associated bloodstream infections, CLABSI, and peripheral venous catheter-associated bloodstream infections, PLABSI; ** central line catheter-associated bloodstream infections, CLABSI only. 
Data on the microbiology of neonatal sepsis collected in this review confirm already known discrepancies between the etiologies of EOS and LOS, as pathogens isolated from EOS cases are mostly derived from the mother's vaginal and skin microbiota. There are, however, notable exceptions, mostly related to GBS infections, as has been found and documented by molecular typing where very early infections are caused by horizontally transmitted hospital GBS strains [48]. Accordingly, prophylaxis for early-onset neonatal sepsis can be attributed to surveillance of antenatal infections performed under the framework of obstetric care by qualified personnel, although standard surveillance in neonatal wards should start immediately after birth to protect infants from early infections transmitted during or immediately following labor.

It should be noted that this review of infections reported and analyzed in high-income countries revealed that most infections (both EOS and LOS) are caused by GBS, S. aureus, and E. coli, regardless of the geographical and cultural differences among patients. This may also suggest that the epidemiology of neonatal infections in these countries reflects high levels of standardization of intensive care. The unusual prevalence of BSI Candida spp. in Italian neonatal intensive care units NICUs may be an early reflection of a new shift in neonatal sepsis etiology to emerging infections caused by C. auris. Owing to difficulties in identification, C. auris isolates may easily be misdiagnosed as other Candida species. Infections caused by this new pathogen have been increasingly reported from India, China, and also the US [49], although the US data included in this review do not indicate this tendency.

\subsection{Prevention and Control of BSI}

Actually, only EOS can be prevented using a proven strategy based on appropriate administration of antibiotics (maternal intrapartum antibiotic prophylaxis, IAP) to stop vaginal colonization by GBS and prevent bacteria from reaching the newborn's oral cavity and upper respiratory tract. At the moment, there are no other approved and implemented methods to prevent EOS and LOS in neonates. It should be mentioned that there are new strategies to detect the threat of EOS, regardless of its etiology, on the basis of serial physical examinations, however, this approach cannot be regarded as preventive. These strategies are implemented in NICUs to reduce laboratory costs and to limit overuse of antibiotics $[50,51]$. The most commonly used among these strategies are related to antibiotic stewardship principles adopted in many NICUs, sometimes under pressure from global campaigns for the prudent use of antibiotics promoted by international and national organizations such as the World Health Organization (WHO), the Infectious Diseases Society of America, the CDC, and the ECDC. In other cases, these strategies are adopted in NICUs in a more reasoned way, based on studies showing the effectiveness of such restrictions. Indeed, there are several studies indicating that monitoring of antibiotic prescribing can result in reduction of unnecessary antibiotic use in the NICU [52].

\subsection{Intrapartum Antibiotic Prophylaxis (IAP)}

The incidence of GBS-caused EOS before introduction of IAP into practice was three to four per 1000 live births. When the first CDC guidelines for IAP were issued in the US during the 1990s, this rate had declined to less than 0.25/1000 live births [52,53]. After the CDC, the American Academy of Pediatrics (AAP), the American College of Obstetricians, and other US organizations issued the most current recommendations which are to be followed for the administration of GBS intrapartum prophylaxis. This procedure is now accepted by the overwhelming majority of national guidelines. Recent reviews on the effectiveness of IAP show that most cases of EOS caused by GBS can be prevented. There are now two methods, routine culture-based screening and risk-based management, which are used to identify mothers requiring IAP during labor [54]. This policy has been implemented in over 90 countries, although microbiological screening for GBS carriage has only been used in $30 \%$ of the countries and clinical risk factor screening has been used for decision making in the remaining countries [55].

IAP has some limitations and links to adverse short- or long-term neonatal effects [56], although there is only one report on serious outcomes of IAP, such as cerebral palsy. Seven observational studies 
showing that IAP alters the infant microbiome were recently analyzed by Seedat [57], however, the clinical significance of the alterations is unknown. There are also observational reports on increased antimicrobial resistance of the gut microbiota bacteria after IAP, however, the data contained in related studies are rather not well documented. Another long-term negative effect of IAP on gut microbiota, is an increased risk of noncommunicable diseases, such as allergies or obesity, which has been observed in neonates exposed to antibiotics during early infancy [58]. Still, it is too early to estimate the negative impact of IAP and early antibiotic treatment of the neonates and their long-term effects. Therefore, it is possible that in the future, GBS vaccination will be applied as EOS prophylaxis during pregnancy either alone or in combination IAP. Most probably, conjugated polyvalent vaccines against both EAO and LOS causing serotypes of GBS will be used. Such practice may decrease GBS infection rates in neonates more effectively than IAP alone [59].

The combined prophylaxis may also prevent late-onset GBS infection, which accounts for approximately $40 \%$ of all GBS neonatal infections. Preterm infants are particularly susceptible to late-onset GBS infections. Actually, neither GBS IAP nor any other neonatal EOS prevention have an effect on late-onset bacterial infection.

\subsection{Implementation of Risk Stratification Strategies for Empirical Use of Antibiotics in Preterm Neonates}

There are other activities that can be regarded as a form of prophylaxis in newborns with risk factors for EOS. Management is well described in official guidelines of the CDC [60], the AAP [61], and the National Institute for Health and Care Excellence [62]. The main component of management is empirical antibiotic therapy given to asymptomatic neonates with known risk factors for EOS, with special regard to chorioamnionitis. Such an approach may reduce sepsis-related morbidity [60], although it has been questioned by some authors [63] as it leads to treating with antibiotics infants without sings of infection. Such overuse of empirical antibiotics may pose a hazard to unaffected infants. Generally, exposure of neonates to antibiotics, either related to IAP or to antibiotic prophylaxis during cesarean delivery or to empirical antibiotics given postnatally to preterm babies, is common. There is growing evidence that exposure to antibiotics is related to increased mortality in premature infants [64]. Moreover, prolonged application of antibiotics in preterm neonates, even without proven infection, may increase the risk of necrotizing enterocolitis (NEC), bronchopulmonary dysplasia, retinopathy, and brain damage $[65,66]$.

Studies on colonization of the gut in newborns and establishment of the gut microbiota show that antibiotics given after birth alter the microbiota composition, enabling its early colonization with potential pathogens derived from the hospital environment and inhibiting colonization with bifidobacteria found in the gut microbiota of neonates born vaginally from healthy mothers [67]. Prolonged, empirical antibiotic treatment severely impairs diversity of the gut microbiota, and promotes pathogens associated with neonatal sepsis which are only minor members of the healthy microbiota [68].

Both the untoward effects related to empirical antibiotic treatment of anyway well-appearing term or late-preterm newborn with risk factors for sepsis and the risk of less significant but common NICU complications, argues in favor of a more carefully thought out management of newborns with sepsis risks [51]. Therefore, to limit antibiotic overtreatment related to empiric therapy given to asymptomatic newborns, new management strategies based on scheduled serial clinical observations, online sepsis risk calculations, and optimized antibiotic dosages have been recently proposed as an alternative to unlimited empiric antibiotics and further evaluation [69,70].

\subsection{Surveillance}

External, nonmaternal risk factors are associated with high intensity of various medical procedures related to the care of newborns with VLBW. These include the use of corticosteroids in newborns with impaired breathing that lower their own neonatal immune response [71] and the necessity for diagnostic and therapeutic invasive procedures (intravascular catheters, respiratory support, and parenteral nutrition), which are risk factors of neonatal LOS [72-75]. The risk of colonization with 
undesirable microorganisms also increases with long-term hospitalization and intensive care of a newborn, especially in overcrowded wards with insufficient staff who are overworked [76-79]. In the US, the average hospital stay for newborns with birth weight $<800 \mathrm{~g}$ is 112 days, and a central catheter (including an umbilical catheter) and mechanical ventilation are used in this group of premature infants on average for $44 \%$ of hospital days in the NICUs ward in newborns with extremely low birth weight, and in up to $11 \%$ in newborns with birth weight $>2500 \mathrm{~g}[80,81]$. In Poland, the average stay of a newborn with VLBW with an infection until it reaches $1800 \mathrm{~g}$ is 44 days, and the CVC utilization ratio is $45 \%$ [82].

According to recent opinions, it is possible to prevent at least some of the health care-associated infections in the NICU with active surveillance. A successful program for the neonatal sepsis surveillance should be based on several activities which include: continuous collection of data on the incidence of the systemic infections; monitoring the spectrum and sensitivities of organisms grown from these infections, controlling utilization rates of the invasive devices; and evaluating interventions and practices implemented to improve the quality of care using bundles. The program should be discussed and constructed by an infection control team or committee with multilevel representation from the unit personnel, preferably separately from but in cooperation with the all-hospital committee.

It has been confirmed that the introduction of the bundles is associated with a reduction in late-onset systemic infections among infants in the NICU [83-85]. The bundles, constructed separately for individual procedures or periods of care, are written locally to better adapt them to the specificities of a unit. Bundles are usually procedures based on evidence-based best practices, which improve care on individual patient. The bundles when applied together, result in substantially greater improvement. For example, activities of the central line bundle, as described by Pharande, include strict hand hygiene, maximal sterile barrier precautions, proper skin antisepsis, aseptic technique, optimal site choice for line insertion, transparent sterile dressing, surveillance, and documentation [85]. According to the authors, implementation of the bundle during a 15-year period resulted in a constant decline in the incidence of LOS and CLABSI in their NICU, in spite of an increase in admissions to the NICU, an increase in central line utilization, and no decrease in the number of high-risk infants. Thus, implementation of multiple infection control bundle practices, together with well-coordinated team efforts and the growing engagement of staff, leads to reduction of the nosocomial infection rates and also strengthening the improvements for a longer time.

The positive results of the implementation of the central line insertion bundle in the NICUs should lead to future implementation of other preventive practices, based on experiences from adult ICUs, for example, a postinsertion care bundle which consists of daily inspection of the insertion site; site care if the dressing is wet, soiled, or has not been changed for seven days; documentation of an ongoing need for the catheter change; proper application of a chlorohexidine-impregnated sponge at the insertion site; scrupulous hand hygiene before supervision of the intravenous line; and disinfection of the infusion hub for $15 \mathrm{~s}$ with alcohol scrub before each entry. Such a CVC postinsertion care bundle was implemented in the adult ICU of the Denver Department of Veterans Affairs and its application was associated with a significant reduction of CLABSI in a setting in which compliance previously introduced central line insertion bundle was already high [84].

\subsection{Probiotics}

Commensal human flora is an extremely valuable first line of defense of the organism, limiting the possibility of invading foreign microorganisms and activating its own immune system. The newborn is in the sterile environment of the mother's womb without exposure to microbes until delivery, and colonization of the newborn in cases of a healthy pregnancy takes place in direct relationship with the mother and the home environment. However, newborns admitted to NICUs are subjected to exposure and colonization with bacterial strains originating from the birth or surgical wards, including from medical personnel. These microorganisms are often characterized by higher resistance to antibiotics and multidrug resistance mechanisms, or even higher virulence [86-91]. 
Meta-analyses have confirmed a reduction in the risk of NEC through the use of probiotics and also the risk of LOS $[92,93]$ in preterm infants, although there is disagreement about the latter entity. Zhang et al. recently stated that probiotic supplementation is safe and may significantly reduce the incidence of LOS in preterm neonates in the NICU [93] but, conversely, meta-analysis of Olsen et al. on prophylactic use of probiotics in preterm infants, did not confirmed a significant reduction in sepsis rates, although a trend toward this effect was noted [94]. Both meta-analyses found a significant reduction in NEC rates, as well as, in general, mortality among neonates after probiotic supplementation but probably in exclusively human milk-fed preterm infants only [95].

The postulated mechanisms of the benefits of probiotics include tight junction (gut barrier) enhancement, modulation of the gut immune system such as toll-like receptor 4 (TLR4), nuclear factor- $\mathrm{B}$, and proinflammatory cytokines, and direct inhibition of gut pathogens, however, the commonly accepted theory on mechanisms of LOS, which is mostly caused by CoNS, is that these skin microbiota members colonize the skin insertion site and catheter hub. From a contaminated hub, microorganisms migrate along the surface of the catheter and enter the bloodstream. This view is supported by in vitro studies, demonstrating that CoNS and, particularly Staphylococcus epidermidis, are able to adhere to plastic surfaces and build a biofilm on them.

The mechanisms of LOS, described above, are evidently not related to the protective activity of probiotics, which is based on correction of the altered gut microbiota toward the elimination of pathogens and tighten gut barrier to prevent bacterial translocation from gut to bloodstream. There are, however, reports supporting the alternative mechanisms of LOS by demonstrating neonatal sepsis cases which have not been related to catheter use but to translocation of bacteria owing to the increased intestinal permeability typical in premature neonates [96-98]. Therefore, it is possible that at least some LOS cases are related to translocation of the potential pathogens colonizing the gut mucosa. Such a mechanism may explain a positive effect of properly selected probiotics on the gut microbiota and, consequently, on the prevention of LOS. We recently observed that oral treatment of VLBW neonates with a mixture of two probiotic bacteria, Bifidobacterium breve and Lactobacillus rhamnosus, was related to significantly lower rates of LOS caused by staphylococci and especially CoNS. These findings may support a view that one mechanism of LOS caused by CoNS may be based on translocation of CoNS, present in large numbers in the gut of VLBW infants, to the bloodstream and not only on colonization and biofilm building on catheter surfaces by CoNS derived from skin microbiota. This hypothesis should be verified in specially designed studies.

Since recent studies stress the importance of the intestinal microbiota alterations in premature neonates as an elementary cause of many diseases in childhood, it seems that a necessary first step is to design novel approaches that correct the microbiota using selected probiotic bacteria as a pioneering organism [99]. Such an approach may lead to early probiotic interventions to prevent LOS in high-risk infants. Well-characterized and clinically proven probiotics should be used for this purpose.

Another concept related to probiotic use is the application of probiotics to pregnant women for the prevention of general preterm morbidity and mortality. Such a possibility has been tested and evaluated.

One of the most exciting scientific advances in recent years has been the realization that commensal microorganisms (our microbiome) play vital roles in human physiology with respect to nutrition, vitamin synthesis, drug metabolism, protection against infection, and recovery from illness. Recent data show that loss of "health-promoting" microbes and overgrowth of pathogenic bacteria (dysbiosis) among patients in the ICU appears to contribute to nosocomial infections, sepsis, and poor outcomes [100]. Overall, accumulating data regarding probiotic and synbiotic therapy reveal a need for definitive clinical trials of these therapies, as recently performed in healthy neonates. Future studies should target administration of probiotics and synbiotics with known mechanistic benefits to improve patient outcomes. Optimally, future probiotic and synbiotic studies will be conducted using microbiome signatures to characterize actual ICU dysbiosis and determine, perhaps even personalize, ideal probiotic and synbiotic therapies. 
Twelve clinical trials have already been analyzed [101] with the authors' conclusion that although safe, it is too early to state whether this preventive strategy is beneficial owing to inconsistency and imprecision of the data. Except for the use of probiotics and prebiotics, prophylactic use of different drugs which may help to promote a healthy gut microbiota and maturation of the immune system in preterm infants is recently proposed. Among these, use of lactoferrin as a promising dietary supplement had been considered, however, the effectiveness of lactoferrin to prevent LOS and NEC in preterm infants and its safety was regarded as controversial. It is noteworthy to mention, that the latest meta-analysis confirms that lactoferrin could significantly reduce the incidence of NEC and LOS and decrease infection-related mortality in premature neonates without obvious adverse effects [102,103].

\section{Discussion}

Surveillance of infections in many different patient populations is well described and functioning, starting from uniform, supranational definitions. Unfortunately, for patients in NICU wards, there is no consensus regarding the principles of surveillance. These differences make it impossible to conduct an unequivocal assessment of the existing epidemiological and microbiological situation in various health care systems, as well as the possibility of implementing elements of prevention. Lack of uniform research tools precludes the design and implementation of supralocal research programs concerning implementation of the various possible solutions described above (Table 6).

Table 6. Potential interventions in early- and late-onset neonatal sepsis prevention and control.

\begin{tabular}{|c|c|}
\hline $\begin{array}{c}\text { Implementation of Various BSI Prevention and } \\
\text { Control Strategies }\end{array}$ & References \\
\hline $\begin{array}{c}\text { Decrease of GBS in EOS: } \\
\text { - } \quad \text { maternal intrapartum antibiotic prophylaxis } \\
\text { - } \quad \text { GBS maternal vaccination (future solution) }\end{array}$ & $\begin{array}{c}{[50-55,104]} \\
{[59,105-108]}\end{array}$ \\
\hline $\begin{array}{c}\text { Decrease of E. coli in EOS: } \\
\text { - E. coli maternal vaccination (future solution) }\end{array}$ & [109] \\
\hline $\begin{array}{l}\text { Decrease of EOS: } \\
\text { - risk stratification of asymptomatic neonates for } \\
\text { empirical use of antibiotics }\end{array}$ & {$[60-62,69,70]$} \\
\hline $\begin{array}{c}\text { Decrease of LOS: } \\
\text { - } \quad \text { surveillance with "bundle of care" strategy } \\
\text { - probiotics }\end{array}$ & $\begin{array}{c}{[83-85]} \\
{[92,93]}\end{array}$ \\
\hline
\end{tabular}

The most prospective and natural way to prevent sepsis, in neonates at risk in the future, seems to be the correction of the gut microbiota composition during the very short but critical period of life just after birth, to enable establishment of bacteria derived from the vaginal microbiota and prevent gut colonization with bacteria from the hospital environment. There are multiple studies showing that preterm infants born by cesarean delivery, who are very prone to sepsis, have altered or disrupted gut microbiota containing potentially pathogenic gram-positive and gram-negative organisms that are often resistant to multiple antibiotics [67].

Although the molecular mechanisms of the early priming immune system period in humans have not been defined, thanks to new animal experiments, there are new data showing that mechanisms of acquiring the gut microbiota in infancy depend on interactions between bacterial, as well as host factors. It was found that the first microbes introduced into young, germ-free, genetically identical mice exert the strongest influence on the gut microbiome [102,103].

Recently, a new mechanism has been demonstrated, which regulates bacterial colonization that is active only during the early neonatal period but also influences life-long microbiota composition. Fulde et al. showed that expression of the flagellin receptor TLR5 in the gut epithelium of mouse neonates is age-dependent [110]. They demonstrated, using microbiota transfer experiments in neonate, adult 
wild-type and TLR5-deficientgerm-free mice, that epithelial TLR5-mediated REG3 $\gamma$ production is critical for the counter-selection of the mucosa-colonizing flagellated bacteria and its expression occurs in neonatal period. This discovery might explain why environmental factors that disturb establishment of the normal microbiota in early life period can affect immune homeostasis and health in adulthood.

There is also new evidence suggesting that gut microbiota composition can have a meaningful impact on the composition of the serum immunoglobulin A (IgA) repertoire and bone marrow plasma cell pool, which may build protection against systemic infection. Wilmore et al. supplemented the gut microbiota of conventional mice with selected proteobacteria and demonstrated that the modification of the microbiota composition caused elevation of the serum IgA concentrations which were correlated with colonization of the bone marrow by large numbers of IgA-secreting plasma cells and marked changes in the serum IgA pool [105].

The actual state of knowledge on gut colonization implicates that the gut microbiota composition is shaped during early infancy but its effect on health is prolonged over adulthood and provides protection against systemic infections. Thus, proper timing and proper bacteria are the crucial factors that may determine successful artificial colonization of neonates at risk. This approach will become more successful when these and other factors are identified in humans and the effects of artificial colonization are proven in clinical trials.

Although the antibiotic prophylaxis against early onset of GBS infection is effective, antibiotics are useless in preventing late onset of the disease in neonates. The introduction of a vaccine for pregnant women in the third trimester is likely to further reduce the burden of disease and provide benefits beyond the prevention of both EOS and LOS, including prevention of meningitis and disability following late-onset infections $[59,105]$. This makes development of the GBS vaccine an important and effective approach for prophylaxis. Up to now, different multivalent conjugate vaccines containing GBS polysaccharide antigens representing the main capsular serotypes of the bacteria have been developed. One of them, a trivalent GBS vaccine, was already successfully evaluated in a phase 1b/2 trial [106].

An immunogenic and protective mucosal vaccine based on inactivated GBS can be as effective as traditional ones but administered orally [107]. Gupalova recently reported the development of a live mucosal vaccine based on a probiotic strain, which is able to induce the appearance of pathogen-specific antibodies owing to the inclusion of antigen of the bacterial pathogen in the structure of the pili protein gene [108]. For this purpose, BAC protein DNA of GBS was integrated into the gene coding for the fimbrial protein D2 of Enterococcus faecium L3 [108], however, this approach seems to have some disadvantages, for example, a risk of using E. faecium, a bacterial species that is an important human pathogen, is the acquisition of extensive antibiotic resistance [111].

E. coli is the second most common organism associated with EOS and other serious bacterial infections in neonates. It is postulated that the common use of IAP has changed the incidence of GBS and E. coli as causes of EOS and LOS. Moreover, increased use of IAP might promote the emergence of multidrug resistant microorganisms that cause EOS, as well as LOS. The most likely way to prevent it could be an anti-E. coli vaccine, that should be effective against strains that are associated with major diseases and resistant to multiple drugs [109,112]. This solution is particularly desirable for populations of special interest, such as pregnant women at risk of preterm labor.

\section{Conclusions}

In the present review, we revealed a diverse pattern in the epidemiology and etiology of neonatal sepsis among 36 OECD countries located on different continents, although the basic data are similar and remain quite homogenous. This may indicate that it is possible to discuss the potential construction and implementation of common and effective surveillance programs for infection prevention and control (IPC) in neonatal wards.

According to the WHO recommendations [1], surveillance of HAI, including neonatal sepsis (or BSI) is critical to inform and guide IPC strategies. Such surveillance should use standardized 
definitions and methodology not only for continuous, everyday infection surveillance but also as a method for evaluating the quality of the data.

Further studies and analyses are certainly needed to achieve modern surveillance programs that will take into account different requirements and various capabilities in the implementation of such programs. The most important obstacle does not seem to be access to modern medical technologies but rather the level of knowledge and skills among professional infection control workers, including interpretation of the microbiological data.

The most prominent differences in the epidemiology of neonatal sepsis collected and presented in this review were observed not in epidemiological indicators but rather in the microbiology of infections, especially LOS. Without in-depth studies, it is difficult to find a cause for these discrepancies, but one possible factor may be differences in the quality of microbiology and laboratory capacities, which are essential for reliable HAI surveillance. The microbiological data on sepsis etiology and pathogen resistance patterns, especially according to EOS and LOS, also provide relevant information on policies of antimicrobial prophylaxis or therapy and antimicrobial resistance-related strategies and interventions.

New approaches to IPC in NICUs underline the necessity to apply multimodal strategies that take into account cooperation among different groups of health care personnel. Thus, a uniform training program in infection control in neonatology is urgently required, together with surveillance programs. Such programs should also involve modern microbiological approaches based on both classical and molecular methods of detection, characterization, and epidemiological typing.

\section{Study Limitations}

This review is based on full texts (original articles or concise communications) written in English. We did our best to find useful data published in other languages, as suggested by Higgins et al. [113], however, not all of the figures we were looking for can be easily found. We were unable to find some useful information on the methodology of infection control in the non-English sources, and therefore we decided to limit the reviews to those written in the English language.

Supplementary Materials: The following are available online at http://www.mdpi.com/2077-0383/8/10/1750/s1, Table S1: The study selection process and search strategy.

Author Contributions: J.W.-M. conceptualized and designed the study and data collection forms, performed the initial searches, extracted the data, the literature review on the epidemiology and microbiology of BSI, drafted the initial manuscript, and approved the final manuscript as submitted; A.C. carried out the initial searches and extracted the data independently, the literature review on the epidemiology and microbiology of BSI, contributed to the draft and approved the final manuscript as submitted; M.S. the literature review on BSI prevention and control, analyzed and interpreted the microbiology data and drafted the manuscript; R.L. the literature review on BSI prevention and control, carried out the initial analyses and drafted the manuscript; P.B.H. conceptualized and designed the study, the literature review on BSI prevention and control, reviewed and revised the manuscript, and approved the final manuscript as submitted.

Funding: This work was supported by the National Science Centre Poland, grant no. UMO-2014/15/B/NZ6/01856 and the National Science Centre Poland, grant no. UMO-2018/31/B/NZ6/02443.

Acknowledgments: We thank Marta Kłos and Maciej Mach for editing the draft of this manuscript.

Conflicts of Interest: The authors declare no conflict of interest.

\section{References}

1. Goldenberg, R.L.; Culhane, J.F.; Iams, J.D.; Romero, R. Epidemiology and causes of preterm birth. Lancet 2008, 371, 75-84. [CrossRef]

2. Martin, J.A.; Hamilton, B.E.; Sutton, P.D.; Ventura, S.J;; Mathews, T.J.; Kirmeyer, S.; Osterman, M.J. Births: Final data for 2007. Natl. Vital Stat. Rep. 2010, 58, 1-85. [PubMed]

3. Auriti, C.; Maccallini, A.; Di Liso, G.; Di Ciommo, V.; Ronchetti, M.; Orzalesi, M. Risk factors for nosocomial infections in a neonatal intensive-care unit. J. Hosp. Infect. 2003, 53, 25-30. [CrossRef] [PubMed] 
4. Drews, M.; Ludwig, A.; Leititis, J.; Daschner, F. Low birth weight and nosocomial infection of neonates in a neonatal intensive care unit. J. Hosp. Infect. 1995, 30, 65-72. [CrossRef]

5. Barton, L.; Hodgman, J.E.; Pavlova, Z. Causes of Death in the Extremely Low Birth Weight Infant. Pediatrics 1999, 103, 446-451. [CrossRef] [PubMed]

6. Stoll, B.J.; Hansen, N. Infections in VLBW infants: Studies from the NICHD Neonatal Research Network. Semin. Perinatol. 2003, 27, 293-301. [CrossRef]

7. Zafar, N.; Wallace, C.M.; Kieffer, P.; Schroeder, P.; Schootman, M.; Hamvas, A. Improving survival of vulnerable infants increases neonatal intensive care unit nosocomial infection rate. Arch. Pediatr. Adolesc. Med. 2001, 155, 1098-1104. [CrossRef]

8. Townsend, T.R.; Wenzel, R.P. Nosocomial bloodstream infections in a newborn intensive care unit: A case-matched control study of morbidity, mortality and risk. Am. J. Epidemiol. 1981, 114, 73-80. [CrossRef]

9. Zingg, W.; Hopkins, S.; Gayet-Ageron, A.; Holmes, A.; Sharland, M.; Suetens, C.; Almeida, M.; Asembergiene, J.; Borg, M.A.; Budimir, A.; et al. Health-care-associated infections in neonates, children, and adolescents: An analysis of paediatric data from the European Centre for Disease Prevention and Control point-prevalence survey. Lancet Infect. Dis. 2017, 17, 381-389. [CrossRef]

10. Health at a Glance 2009: OECD Indicators. 1.9. Infant Health: Low Birth Weight. Available online: www.oecd-library.org (accessed on 5 July 2019).

11. Singh, T.; Barnes, E.H.; Isaacs, D. Australian Study Group for Neonatal Infections: Early-onset neonatal infections in Australia and New Zealand, 2002-2012. Arch. Dis. Child.-Fetal Neonatal Ed. 2019, 104, F248-F252. [CrossRef]

12. Worth, L.J.; Daley, A.J.; Spelman, T.; Bull, A.L.; Brett, A.J.; Richards, M.J. Central and peripheral line-associated bloodstream infections in Australian neonatal and paediatric intensive care units: Findings from a comprehensive Victorian surveillance network, 2008-2016. J. Hosp. Infect. 2017, 99, 55-61. [CrossRef] [PubMed]

13. Hossain, S.; Shah, P.S.; Ye, X.Y.; Darlow, B.A.; Lee, S.K.; Lui, K.; Canadian Neonatal Network; Australian and New Zealand Neonatal Network. Outcome comparison of very preterm infants cared for in the neonatal intensive care units in Australia and New Zealand and in Canada. J. Paediatr. Child Health 2015, 51, 881-888. [CrossRef] [PubMed]

14. Berger, A.; Salzer, H.; Weninger, M.; Sageder, B.; Aspöck, C. Septicaemia in an Austrian neonatal intensive care unit: A 7-year analysis. Acta Paediatr. 1998, 87, 1066-1069. [CrossRef]

15. Verstraete, E.H.; Mahieu, L.; De Coen, K.; Vogelaers, D.; Blot, S. Impact of healthcare-associated sepsis on mortality in critically ill infants. Eur. J. Nucl. Med. Mol. Imaging 2016, 175, 943-952. [CrossRef] [PubMed]

16. Drageset, M.; Fjalstad, J.W.; Mortensen, S.; Klingenberg, C. Management of early-onset neonatal sepsis differs in the north and south of Scandinavia. Acta Paediatr. 2017, 106, 375-381. [CrossRef]

17. Olsen, A.L.; Reinholdt, J.; Jensen, A.M.; Andersen, L.P.; Jensen, E.T. Nosocomial infection in a Danish Neonatal Intensive Care Unit: A prospective study. Acta Paediatr. 2009, 98, 1294-1299. [CrossRef]

18. Mitt, P.; Metsvaht, T.; Adamson, V.; Telling, K.; Naaber, P.; Lutsar, I.; Maimets, M. Five-year prospective surveillance of nosocomial bloodstream infections in an Estonian paediatric intensive care unit. J. Hosp. Infect. 2014, 86, 95-99. [CrossRef]

19. Sarvikivi, E.; Lyytikäinen, O.; Vaara, M.; Saxen, H. Nosocomial bloodstream infections in children: An 8-year experience at a tertiary-care hospital in Finland. Clin. Microbiol. Infect. 2008, 14, 1072-1075. [CrossRef]

20. Kuhn, P.; Dheu, C.; Bolender, C.; Chognot, D.; Keller, L.; DeMil, H.; Donato, L.; Langer, B.; Messer, J.; Astruc, D. Incidence and distribution of pathogens in early-onset neonatal sepsis in the era of antenatal antibiotics. Paediatr. Périnat. Epidemiol. 2010, 24, 479-487. [CrossRef]

21. Didier, C.; Streicher, M.P.; Chognot, D.; Campagni, R.; Schnebelen, A.; Messer, J.; Donato, L.; Langer, B.; Meyer, N.; Astruc, D.; et al. Late-onset neonatal infections: Incidences and pathogens in the era of antenatal antibiotics. Eur. J. Pediatr. 2012, 171, 681-687. [CrossRef]

22. Geffers, C.; Baerwolff, S.; Schwab, F.; Gastmeier, P. Incidence of healthcare-associated infections in high-risk neonates: Results from the Germen surveillance system for very-low-birthweight infants. J. Hosp. Infect. 2008, 68, 214-221. [CrossRef] [PubMed]

23. Salm, F.; Schwab, F.; Geffers, C.; Gastmeier, P.; Piening, B. The Implementation of an Evidence-Based Bundle for Bloodstream Infections in Neonatal Intensive Care Units in Germany: A Controlled Intervention Study to Improve Patient Safety. Infect. Control. Hosp. Epidemiol. 2016, 37, 798-804. [CrossRef] [PubMed] 
24. Gkentzi, D.; Kortsalioudaki, C.; Cailes, B.C.; Zaoutis, T.; Kopsidas, J.; Tsolia, M.; Spyridis, N.; Siahanidou, S.; Sarafidis, K.; Heath, P.T.; et al. Epidemiology of infections and antimicrobial use in Greek Neonatal Units. Arch. Dis. Child.-Fetal Neonatal Ed. 2018, 104, F293-F297. [CrossRef] [PubMed]

25. Huggard, D.; Drew, R.; McCallion, N. Neonatal Bacteraemia among 112,360 Live Births. Ir. Med. J. 2016, 109, 467. [PubMed]

26. Makhoul, I.R.; Sujov, P.; Smolkin, T.; Lusky, A.; Reichman, B. Epidemiological, clinical, and microbiological characteristics of late-onset sepsis among very low birth weight infants in Israel: A national survey. Pediatrics 2002, 109, 34-39. [CrossRef]

27. Klinger, G.; Levy, I.; Sirota, L.; Boyko, V.; Lerner-Geva, L.; Reichman, B.; Israel Neonatal Network. Outcome of Early-Onset Sepsis in a National Cohort of Very Low Birth Weight Infants. Pediatrics 2010, 125, e736-e740. [CrossRef]

28. Bulkowstein, S.; Ben-Shimol, S.; Givon-Lavi, N.; Melamed, R.; Shany, E.; Greenberg, D. Comparison of early onset sepsis and community-acquired late onset sepsis in infants less than 3 months of age. BMC Pediatr. 2016, 16, 82. [CrossRef]

29. Crivaro, V.; Bogdanović, L.; Bagattini, M.; Iula, V.D.; Catania, M.; Raimondi, F.; Triassi, M.; Zarrilli, R. Surveillance of healthcare-associated infections in a neonatal intensive care unit in Italy during 2006-2010. BMC Infect. Dis. 2015, 15, 152. [CrossRef]

30. Morioka, I.; Morikawa, S.; Miwa, A.; Minami, H.; Yoshii, K.; Kugo, M.; Kitsunezuka, Y.; Enomoto, M.; Jikimoto, T.; Nakamura, M.; et al. Culture-Proven Neonatal Sepsis in Japanese Neonatal Care Units in 2006-2008. Neonatology 2012, 102, 75-80. [CrossRef]

31. Leal, Y.A.; Álvarez-Nemegyei, J.; Velázquez, J.R.; Rosado-Quiab, U.; Diego-Rodríguez, N.; Paz-Baeza, E.; Dávila-Velázquez, J. Risk factors and prognosis for neonatal sepsis in southeastern Mexico: Analysis of a four-year historic cohort follow-up. BMC Pregnancy Childbirth 2012, 12, 48. [CrossRef]

32. Yumani, D.F.; van den Dungen, F.A.; van Weissenbruch, M.M. Incidence and risk factors for catheter-associated bloodstream infections in neonatal intensive care. Acta Paediatr. 2013, 102, e293-e298. [CrossRef] [PubMed]

33. Hornik, C.P.; Fort, P.; Clark, R.H.; Watt, K.; Benjamin, D.K., Jr.; Smith, P.B.; Manzoni, P.; Jacqz-Aigrain, E.; Kaguelidou, F.; Cohen-Wolkowiez, M.; et al. Early and late onset sepsis in very-low-birth-weight infants from a large group of neonatal intensive care units. Early Hum. Dev. 2012, 88, S69-S74. [CrossRef]

34. Rønnestad, A.; Abrahamsen, T.G.; Medbø, S.; Reigstad, H.; Lossius, K.; Kaaresen, P.I.; Engelund, I.E.; Irgens, L.M.; Markestad, T. Septicemia in the First Week of Life in a Norwegian National Cohort of Extremely Premature Infants. Pediatrics 2005, 115, e262-e268. [CrossRef] [PubMed]

35. Rønnestad, A.; Abrahamsen, T.G.; Medbø, S.; Reigstad, H.; Lossius, K.; Kaaresen, P.I.; Egeland, T.; Engelund, I.E.; Irgens, L.M.; Markestad, T. Late-Onset Septicemia in a Norwegian National Cohort of Extremely Premature Infants Receiving Very Early Full Human Milk Feeding. Pediatrics 2005, 115, e269-e276. [CrossRef]

36. Wojkowska-Mach, J.; Borszewska-Kornacka, M.; Domańska, J.; Gadzinowski, J.; Gulczyńska, E.; Helwich, E.; Kordek, A.; Pawlik, D.; Szczapa, J.; Klamka, J.; et al. Early-onset Infections of Very-low-birth-weight Infants in Polish Neonatal Intensive Care Units. Pediatr. Infect. Dis. J. 2012, 31, 691-695. [CrossRef]

37. Wójkowska-Mach, J.; Gulczyńska, E.; Nowiczewski, M.; Borszewska-Kornacka, M.; Domańska, J.; Merritt, T.A.; Helwich, E.; Kordek, A.; Pawlik, D.; Gadzinowski, J.; et al. Late-onset bloodstream infections of Very-Low-Birth-Weight infants: Data from the Polish Neonatology Surveillance Network in 2009-2011. BMC Infect. Dis. 2014, 14, 339. [CrossRef]

38. Escalante, M.J.; Ceriani-Cernadas, J.M.; D’Apremont, I.; Escalante, M.J.; Ceriani-Cernadas, J.M.; D’Apremont, I.; Bancalari, A.; Webb, V.; Genes, L.; Villarroel, L.; et al. NEOCOSUR Neonatal Network: Late Onset Sepsis in Very Low Birth Weight Infants in the South American NEOCOSUR Network. Pediatr. Infect. Dis. J. 2018, 37, 1022-1027. [CrossRef]

39. Shin, Y.-J.; Ki, M.; Foxman, B. Epidemiology of neonatal sepsis in South Korea. Pediatr. Int. 2009, 51, $225-232$. [CrossRef]

40. Moro, M.; Perez-Rodriguez, J.; Figueras-Aloy, J.; Fernández, C.; Doménech, E.; Jiménez, R.; Pérez-Sheriff, V.; Quero, J.; Roques, V. Predischarge morbidities in extremely and very low-birth-weight infants in Spanish neonatal units. Am. J. Perinatol. 2009, 26, 335-343. [CrossRef]

41. Ohlin, A.; Björkman, L.; Serenius, F.; Schollin, J.; Källén, K. Sepsis as a risk factor for neonatal morbidity in extremely preterm infants. Acta Paediatr. 2015, 104, 1070-1076. [CrossRef] 
42. Giannoni, E.; Agyeman, P.K.; Stocker, M.; Posfay-Barbe, K.M.; Heininger, U.; Spycher, B.D.; Bernhard-Stirnemann, S.; Niederer-Loher, A.; Kahlert, C.R.; Donas, A.; et al. Swiss Pediatric Sepsis Study Neonatal Sepsis of Early Onset, and Hospital-Acquired and Community-Acquired Late Onset: A Prospective Population-Based Cohort Study. J. Pediatr. 2018, 201, 106-114. [CrossRef] [PubMed]

43. Cetinkaya, M.; Koksal, N.; Ozkan, H.; Celebi, S.; Hacimustafaoglu, M. Culture-proven neonatal sepsis in preterm infants in a neonatal intensive care unit over a 7-year period: Coagulase-negative Staphylococcus as the predominant pathogen. Pediatr. Int. 2014, 56, 60-66.

44. Cailes, B.; Kortsalioudaki, C.; Buttery, J.; Pattnayak, S.; Greenough, A.; Matthes, J.; Bedford Russell, A.; Kennea, N.; Heath, P.T.; neonIN network. Epidemiology of UK neonatal infections: The neonIN infection surveillance network. Arch. Dis. Child.-Fetal Neonatal Ed. 2018, 103, F547-F553. [CrossRef] [PubMed]

45. Stoll, B.J.; Hansen, N.; Fanaroff, A.A.; Wright, L.L.; Carlo, W.A.; Ehrenkranz, R.A.; Lemons, J.A.; Donovan, E.F.; Stark, A.R.; Tyson, J.E.; et al. Changes in Pathogens Causing Early-Onset Sepsis in Very-Low-Birth-Weight Infants. N. Engl. J. Med. 2002, 347, 240-247. [CrossRef] [PubMed]

46. Shane, A.L.; Sánchez, P.J.; Stoll, B.J. Neonatal sepsis. Lancet 2017, 390, 1770-1780. [CrossRef]

47. Wynn, J.L.; Wong, H.R.; Shanley, T.P.; Bizzarro, M.J.; Saiman, L.; Polin, R.A. Time for a neonatal-specific consensus definition for sepsis. Pediatr. Crit. Care Med. 2014, 15, 523-528. [CrossRef]

48. Strus, M.; Pawlik, D.; Brzychczy-Włoch, M.; Gosiewski, T.; Rytlewski, K.; Lauterbach, R.; Heczko, P.B. Group $\mathrm{B}$ streptococcus colonization of pregnant women and their children observed on obstetric and neonatal wards of the University Hospital in Krakow, Poland. J. Med. Microbiol. 2009, 58, 228-233. [CrossRef]

49. Sardi, J.D.C.O.; Silva, D.R.; Mendes-Giannini, M.J.S.; Rosalen, P.L. Candida auris: Epidemiology, risk factors, virulence, resistance, and therapeutic options. Microb. Pathog. 2018, 125, 116-121. [CrossRef]

50. Berardi, A.; Tzialla, C.; Travan, L.; Bua, J.; Santori, D.; Azzalli, M.; Spada, C.; Lucaccioni, L.; GBS Prevention Working Group of Emilia-Romagna. Secondary prevention of early-onset sepsis: A less invasive Italian approach for managing neonates at risk. Ital. J. Pediatr. 2018, 44, 73-77. [CrossRef]

51. Hooven, T.A.; Randis, T.M.; Polin, R.A. What's the harm? Risks and benefits of evolving rule-out sepsis practices. J. Perinatol. 2018, 38, 614-622. [CrossRef]

52. McCarthy, K.N.; Hawke, A.; Dempsey, E.M. Antimicrobial stewardship in the neonatal unit reduces antibiotic exposure. Acta Paediatr. 2018, 107, 1716-1721. [CrossRef] [PubMed]

53. Benitz, W.E.; Wynn, J.L.; Polin, R.A. Reappraisal of guidelines for management of neonates with suspected early-onset sepsis. J. Pediatr. 2015, 166, 1070-1074. [CrossRef] [PubMed]

54. Kurz, E.; Davis, D. Routine culture-based screening versus risk-based management for the prevention of early-onset group B streptococcus disease in the neonate: A systematic review. JBI Database Syst. Rev. Implement. Rep. 2015, 13, 206-246. [CrossRef] [PubMed]

55. Le Doare, K.; O’driscoll, M.; Turner, K.; Seedat, F.; Russell, N.J.; Seale, A.C.; Heath, P.T.; Lawn, J.E.; Baker, C.J.; Bartlett, L.; et al. GBS Intrapartum Antibiotic Investigator Group. Intrapartum Antibiotic Chemoprophylaxis Policies for the Prevention of Group B Streptococcal Disease Worldwide: Systematic Review. Clin. Infect. Dis. 2017, 65, S143-S151. [CrossRef] [PubMed]

56. Braye, K.; Ferguson, J.; Davis, D.; Catling, C.; Monk, A.; Foureur, M. Effectiveness of intrapartum antibiotic prophylaxis for early-onset group B Streptococcal infection: An integrative review. Women Birth 2018, 31, 244-253. [CrossRef]

57. Seedat, F.; Stinton, C.; Patterson, J.; Geppert, J.; Tan, B.; Robinson, E.R.; McCarthy, N.D.; Uthman, O.A.; Freeman, K.; Johnson, S.A.; et al. Adverse events in women and children who have received intrapartum antibiotic prophylaxis treatment: A systematic review. BMC Pregnancy Childbirth 2017, 17, 247. [CrossRef]

58. Walker, W.A. The importance of appropriate initial bacterial colonization of the intestine in newborn, child, and adult health. Pediatr. Res. 2017, 82, 387-395. [CrossRef]

59. Kenchington, A.L.; Lamont, R.F. Group B streptococcal immunisation of pregnant women for the prevention of early and late onset Group B streptococcal infection of the neonate as well as adult disease. Expert Rev. Vaccines 2017, 16, 15-25. [CrossRef]

60. Verani, J.R.; McGee, L.; Schrag, S.J. Prevention of perinatal group B streptococcal disease-Revised guidelines from CDC, 2010. MMWR Recomm. Rep. 2010, 59, 1-36.

61. Polin, R.A.; Papile, L.-A.; Baley, J.E.; Bhutani, V.K.; Carlo, W.A.; Cummings, J.; Kumar, P.; Tan, R.C.; Wang, K.S.; Watterberg, K.L. Management of Neonates With Suspected or Proven Early-Onset Bacterial Sepsis. Pediatrics 2012, 129, 1006-1015. [CrossRef] 
62. National Collaborating Centre for Women's and Children's Health (UK). Antibiotics for Early-Onset Neonatal Infection: Anti-Biotics for the Prevention and Treatment of Early-Onset Neonatal Infection; Nice Clinical Guidelines, No. 149; Rcog Press: London, UK, 2012.

63. Wortham, J.M.; Hansen, N.I.; Schrag, S.J.; Hale, E.; Van Meurs, K.; Sánchez, P.J.; Cantey, J.B.; Faix, R.; Poindexter, B.; Goldberg, R.; et al. Chorioamnionitis and Culture-Confirmed, Early-Onset Neonatal Infections. Pediatrics 2016, 137. [CrossRef] [PubMed]

64. Mukhopadhyay, S.; Puopolo, K.M. Antibiotic Use and Mortality Among Premature Infants without Confirmed Infection-Perpetrator or Innocent Bystander? JAMA Pediatr. 2016, 170, 1144-1146. [CrossRef] [PubMed]

65. Ting, J.Y.; Synnes, A.; Roberts, A.; Deshpandey, A.; Dow, K.; Yoon, E.W.; Lee, K.-S.; Dobson, S.; Lee, S.K.; Shah, P.S.; et al. Association Between Antibiotic Use and Neonatal Mortality and Morbidities in Very Low-Birth-Weight Infants Without Culture-Proven Sepsis or Necrotizing Enterocolitis. JAMA Pediatr. 2016, 170, 1181-1187. [CrossRef] [PubMed]

66. Esaiassen, E.; Fjalstad, J.W.; Juvet, L.K.; van den Anker, J.N.; Klingenberg, C. Antibiotic exposure in neonates and early adverse outcomes: A systematic review and meta-analysis. J. Antimicrob. Chemother. 2017, 72, 1858-1870. [CrossRef] [PubMed]

67. Isolauri, E.; Sherman, P.; Walker, W. Bacterial Colonization of the Newborn Gut, Immune Development, and Prevention of Disease. Nestlé Nutr. Inst. Workshop Ser. 2017, 88, 23-33.

68. Madan, J.C.; Salari, R.C.; Saxena, D.; Davidson, L.; O’Toole, G.A.; Moore, J.H.; Sogin, M.L.; Foster, J.A.; Edwards, W.H.; Palumbo, P.; et al. Gut microbial colonisation in premature neonates predicts neonatal sepsis. Arch. Dis. Child.-Fetal Neonatal Ed. 2012, 97, F456-F462. [CrossRef]

69. Puopolo, K.M.; Benitz, W.E.; Zaoutis, T.E.; Committee on Fetus and Newborn. Committee on Infectious Diseases Management of Neonates Born at $\leq 34$ 6/7 Weeks' Gestation With Suspected or Proven Early-Onset Bacterial Sepsis. Pediatrics 2018, 142, e20182896. [CrossRef]

70. van Donge, T.; Bielicki, J.A.; van den Anker, J.; Pfister, M. Key Components for Antibiotic Dose Optimization of Sepsis in Neonates and Infants. Front. Pediatr. 2018, 6, 325. [CrossRef]

71. Bancalari, E. Corticosteroids and neonatal chronic lung disease. Eur. J. Pediatr. 1998, 157, S31-S37. [CrossRef]

72. Chien, L.-Y.; Macnab, Y.; Aziz, K.; Andrews, W.; McMillan, D.D.; Lee, S.K. Variations in central venous catheter-related infection risks among Canadian neonatal intensive care units. Pediatr. Infect. Dis. J. 2002, 21,505-511. [CrossRef]

73. Hruszkewycz, V.; Holtrop, P.C.; Batton, D.G.; Band, J.D.; Morden, R.S.; Gibson, P. Complications Associated with Central Venous Catheters Inserted in Critically Ill Neonates. Infect. Control. Hosp. Epidemiol. 1991, 12, 544-548. [CrossRef] [PubMed]

74. Freeman, J.; Goldmann, D.A.; Smith, N.E.; Sidebottom, D.G.; Epstein, M.F.; Platt, R. Association of Intravenous Lipid Emulsion and Coagulase-Negative Staphylococcal Bacteremia in Neonatal Intensive Care Units. N. Engl. J. Med. 1990, 323, 301-308. [CrossRef] [PubMed]

75. Landers, S.; Moise, A.A.; Fraley, J.K.; Smith, E.O.; Baker, C.J. Factors Associated With Umbilical Catheter-Related Sepsis in Neonates. Am. J. Dis. Child. 1991, 145, 675-680. [CrossRef] [PubMed]

76. Cordero, L.; Ayers, L.W.; Davis, K. Neonatal airway colonization with Gram-negative bacilli: Association with severity of bronchopulmonary dysplasia. Pediatr. Infect. Dis. J. 1997, 16, 18-23. [CrossRef] [PubMed]

77. Haley, R.W.; Cushion, N.B.; Tenover, F.C.; Bannerman, T.L.; Dryer, D.; Ross, J.; Sánchez, P.J.; Siegel, J.D. Eradication of Endemic Methicillin-Resistant Staphylococcus Aureus Infections from a Neonatal Intensive Care Unit. J. Infect. Dis. 1995, 171, 614-624. [CrossRef]

78. Archibald, L.K.; Manning, M.L.; Bell, L.M.; Banerjee, S.; Jarvis, W.R. Patient density, nurse-to-patient ratio and nosocomial infection risk in a pediatric cardiac intensive care unit. Pediatr. Infect. Dis. J. 1997, 16, 1045-1048. [CrossRef]

79. Harbarth, S.; Sudre, P.; Dharan, S.; Cadenas, M.; Pittet, D. Outbreak of Enterobacter cloacae Related to Understaffing, Overcrowding, and Poor Hygiene Practices. Infect. Control. Hosp. Epidemiol. 1999, 20, 598-603. [CrossRef]

80. Gladstone, I.M.; Ehrenkranz, R.A.; Edberg, S.C.; Baltimore, R.S. A ten-year review of neonatal sepsis and comparison with the previous fifty-year experience. Pediatr. Infect. Dis. J. 1990, 9, 819-890. [CrossRef]

81. Dudeck, M.A.; Edwards, J.R.; Allen-Bridson, K.; Gross, C.; Malpiedi, P.J.; Peterson, K.D.; Pollock, D.A.; Weiner, L.M.; Sievert, D.M. National Healthcare Safety Network report, data summary for 2013, Device-associated Module. Am. J. Infect. Control. 2015, 43, 206-221. [CrossRef] 
82. Różańska, A.; Wojkowska-Mach, J.; Adamski, P.; Borszewska-Kornacka, M.; Gulczynska, E.; Nowiczewski, M.; Helwich, E.; Kordek, A.; Pawlik, D.; Bulanda, M. Infections and risk-adjusted length of stay and hospital mortality in Polish Neonatology Intensive Care Units. Int. J. Infect. Dis. 2015, 35, 87-92. [CrossRef]

83. Wirtschafter, D.D.; Pettit, J.; Kurtin, P.; Dalsey, M.; Chance, K.; Morrow, H.W.; Seid, M.; Byczkowski, T.L.; Huber, T.P.; Milstein, J.M.; et al. A statewide quality improvement collaborative to reduce neonatal central line-associated blood stream infections. J. Perinatol. 2010, 30, 170-181. [CrossRef] [PubMed]

84. Guerin, K.; Wagner, J.; Rains, K.; Bessesen, M. Reduction in central line-associated bloodstream infections by implementation of a postinsertion care bundle. Am. J. Infect. Control. 2010, 38, 430-433. [CrossRef] [PubMed]

85. Pharande, P.; Lindrea, K.B.; Smyth, J.; Evans, M.; Lui, K.; Bolisetty, S. Trends in late-onset sepsis in a neonatal intensive care unit following implementation of infection control bundle: A 15-year audit. J. Paediatr. Child Health 2018, 54, 1314-1320. [CrossRef] [PubMed]

86. Bialkowska-Hobrzanska, H.; Jaskot, D.; Hammerberg, O. Molecular characterization of the coagulase-negative staphylococcal surface flora of premature neonates. J. Gen. Microbiol. 1993, 139, 2939-2944. [CrossRef]

87. Goldmann, D.A.; LeClair, J.; Macone, A. Bacterial colonization of neonates admitted to an intensive care environment. J. Pediatr. 1978, 93, 288-293. [CrossRef]

88. Goldmann, D.A. The bacterial flora of neonates in intensive care-Monitoring and manipulation. J. Hosp. Infect. 1988, 11, 340-351. [CrossRef]

89. D'Angio, C.T.; McGowan, K.L.; Baumgart, S.; Geme, J.S.; Harris, M.C. Surface colonization with coagulase-negative staphylococci in premature neonates. J. Pediatr. 1989, 114, 1029-1034. [CrossRef]

90. Savey, A.; Fleurette, J.; Salle, B. An analysis of the microbial flora of premature neonates. J. Hosp. Infect. 1992, 21, 275-289. [CrossRef]

91. Fujita, K.; Murono, K. Nosocomial acquisition of Escherichia coli by infants delivered in hospitals. J. Hosp. Infect. 1996, 32, 277-281. [CrossRef]

92. Rao, S.C.; Athalye-Jape, G.K.; Deshpande, G.C.; Simmer, K.N.; Patole, S.K. Probiotic Supplementation and Late-Onset Sepsis in Preterm Infants: A Meta-analysis. Pediatrics 2016, 137, e20153684. [CrossRef]

93. Zhang, G.Q.; Hu, H.J.; Liu, C.Y.; Shakya, S.; Li, Z.Y. Probiotics for Preventing Late-Onset Sepsis in Preterm Neonates: A PRISMA-Compliant Systematic Review and Meta-Analysis of Randomized Controlled Trials. Medicine 2016, 95, e2581. [CrossRef] [PubMed]

94. Olsen, R.; Greisen, G.; Schrøder, M.; Brok, J. Prophylactic Probiotics for Preterm Infants: A Systematic Review and Meta-Analysis of Observational Studies. Neonatology 2016, 109, 105-112. [CrossRef] [PubMed]

95. Aceti, A.; Maggio, L.; Beghetti, I.; Gori, D.; Barone, G.; Callegari, M.; Fantini, M.; Indrio, F.; Meneghin, F.; Morelli, L.; et al. Probiotics Prevent Late-Onset Sepsis in Human Milk-Fed, Very Low Birth Weight Preterm Infants: Systematic Review and Meta-Analysis. Nutrients 2017, 9, 904. [CrossRef] [PubMed]

96. Cheung, G.Y.C.; Otto, M. Understanding the significance of Staphylococcus epidermidis bacteremia in babies and children. Curr. Opin. Infect. Dis. 2010, 23, 208-216. [CrossRef]

97. Ciftci, I.; Ozdemir, M.; Aktan, M.; Aslan, K. Bacterial translocation and intestinal injury in experimental necrotizing enterocolitis model. Bratisl. Lek. List. 2012, 113, 206-210. [CrossRef]

98. Deitch, E.A. Gut-origin sepsis: Evolution of a concept. Surgeon 2012, 10, 350-356. [CrossRef]

99. Mihatsch, W.A.; Braegger, C.P.; Decsi, T.; Kolaček, S.; Lanzinger, H.; Mayer, B.; Moreno, L.A.; Pohlandt, F.; Puntis, J.; Shamir, R.; et al. Critical systematic review of the level of evidence for routine use of probiotics for reduction of mortality and prevention of necrotizing enterocolitis and sepsis in preterm infants. Clin. Nutr. 2012, 31, 6-15. [CrossRef]

100. Davison, J.M.; Wischmeyer, P.E. Probiotic and synbiotic therapy in the critically ill: State of the art. Nutrition 2018, 59, 29-36. [CrossRef]

101. Grev, J.; Berg, M.; Soll, R. Maternal probiotic supplementation for prevention of morbidity and mortality in preterm infants. Cochrane Database Syst. Rev. 2018, 12, CD012519. [CrossRef]

102. He, Y.; Cao, L.; Yu, J. Prophylactic lactoferrin for preventing late-onset sepsis and necrotizing enterocolitis in preterm infants: A PRISMA-compliant systematic review and meta-analysis. Medicine 2018, 97, e11976. [CrossRef]

103. Martínez, I.; Maldonado-Gomez, M.X.; Gomes-Neto, J.C.; Kittana, H.; Ding, H.; Schmaltz, R.; Joglekar, P.; Cardona, R.J.; Marsteller, N.L.; Kembel, S.W.; et al. Experimental evaluation of the importance of colonization history in early-life gut microbiota assembly. eLife 2018, 7, e36521. [CrossRef] [PubMed] 
104. Verani, J.R.; Schrag, S.J. Group B streptococcal disease in infants: Progress in prevention and continued challenges. Clin. Perinatol. 2010, 37, 375-392. [CrossRef] [PubMed]

105. Wilmore, J.R.; Gaudette, B.T.; Atria, D.G.; Hashemi, T.; Jones, D.D.; Gardner, C.A.; Cole, S.D.; Misic, A.M.; Beiting, D.P.; Allman, D. Commensal Microbes Induce Serum IgA Responses that Protect against Polymicrobial Sepsis. Cell Host Microbe 2018, 23, 302-311. [CrossRef] [PubMed]

106. Madhi, S.A.; Cutland, C.L.; Jose, L.; Koen, A.; Govender, N.; Wittke, F.; Olugbosi, M.; Sobanjo-ter Meulen, A.; Baker, S.; Dull, P.M.; et al. Safety and immunogenicity of an investigational maternal in healthy women and their infants: A randomised phase 1b/2 trial. Lancet Infect. Dis. 2016, 16, 923-934. [CrossRef]

107. Baker, J.A.; Lewis, E.L.; Byland, L.M.; Bonakdar, M.; Randis, T.M.; Ratner, A.J. Mucosal vaccination promotes clearance of Streptococcus agalactiae vaginal colonization. Vaccine 2017, 35, 1273-1280. [CrossRef] [PubMed]

108. Gupalova, T.; Leontieva, G.; Kramskaya, T.; Grabovskaya, K.; Bormotova, E.; Korjevski, D.; Suvorov, A. Development of experimental GBS vaccine for mucosal immunization. PLoS ONE 2018, 13, e0196564. [CrossRef]

109. Bauserman, M.S.; Laughon, M.M.; Hornik, C.P.; Smith, P.B.; Benjamin, D.K.; Clark, R.H.; Engmann, C.; Cohen-Wolkowiez, M. Group B Streptococcus and Escherichia coli infections in the intensive care nursery in the era of intrapartum antibiotic prophylaxis. Pediatr. Infect. Dis. J. 2013, 32, 208-212. [CrossRef]

110. Fulde, M.; Sommer, F.; Chassaing, B.; Van Vorst, K.; Dupont, A.; Hensel, M.; Basic, M.; Klopfleisch, R.; Rosenstiel, P.; Bleich, A.; et al. Neonatal selection by Toll-like receptor 5 influences long-term gut microbiota composition. Nature 2018, 560, 489-493. [CrossRef]

111. Gao, W.; Howden, B.P.; Stinear, T.P. Evolution of virulence in Enterococcus faecium, a hospital-adapted opportunistic pathogen. Curr. Opin. Microbiol. 2018, 41, 76-82. [CrossRef]

112. Poolman, J.T.; Wacker, M. Extraintestinal Pathogenic Escherichia coli, a Common Human Pathogen: Challenges for Vaccine Development and Progress in the Field. J. Infect. Dis. 2016, 213, 6-13. [CrossRef]

113. Higgins, J.P.T.; Green, S. (Eds.) Cochrane Handbook for Systematic Reviews of Interventions Version 5.1.0 [updated March 2011]; Cochrane Collaboration: London, UK, 2011; Available online: www.cochrane-handbook.org (accessed on 21 October 2019).

(C) 2019 by the authors. Licensee MDPI, Basel, Switzerland. This article is an open access article distributed under the terms and conditions of the Creative Commons Attribution (CC BY) license (http://creativecommons.org/licenses/by/4.0/). 